\title{
3D Printing: Advancement in Biogenerative Engineering to Combat Shortage of Organs and Bioapplicable Materials
}

\author{
Arpana Parihar ${ }^{1,2}$ (I) $\cdot$ Vasundhara Pandita $^{1} \cdot$ Avinash Kumar $^{3} \cdot$ Dipesh Singh Parihar $^{4} \cdot$ Nidhi Puranik $^{1} \cdot$ Tapas Bajpai $^{5}$. \\ Raju Khan ${ }^{2,6}$
}

Received: 28 January 2021 / Revised: 26 May 2021 / Accepted: 8 June 2021 / Published online: 2 July 2021

(C) The Regenerative Engineering Society 2021

\begin{abstract}
Organ or cell transplantation is medically evaluated for end-stage failure saving or extending the lives of thousands of patients who are suffering from organ failure disorders. The unavailability of adequate organs for transplantation to meet the existing demand is a major challenge in the medical field. This led to day-day-increase in the number of patients on transplant waiting lists as well as in the number of patients dying while on the queue. Recently, technological advancements in the field of biogenerative engineering have the potential to regenerate tissues and, in some cases, create new tissues and organs. In this context, major advances and innovations are being made in the fields of tissue engineering and regenerative medicine which have a huge impact on the scientific community is three-dimensional bioprinting (3D bioprinting) of tissues and organs. Besides this, the decellularization of organs and using this as a scaffold for generating new organs through the recellularization process shows promising results. This review discussed about current approaches for tissue and organ engineering including methods of scaffold designing, recent advances in 3D bioprinting, organs regenerated successfully using 3D printing, and extended application of 3D bioprinting technique in the field of medicine. Besides this, information about commercially available 3D printers has also been included in this article.
\end{abstract}

\section{Lay Summary}

Today's need for organs for the transplantation process in order to save a patient's life or to enhance the survival rate of diseased one is the prime concern among the scientific community. Recent, advances in the field of biogenerative engineering have the potential to regenerate tissues and create organs compatible with the patient's body. In this context, major advances and innovations are being made in the fields of tissue engineering and regenerative medicine which have a huge impact on the scientific community is three-dimensional bioprinting (3D bioprinting) of tissues and organs. Besides this, the decellularization of organs and using this as a scaffold for generating new organs through the recellularization process shows promising results. This review dealt with the current approaches for tissue and organ engineering including methods of scaffold designing, recent advances in 3D bioprinting, organs regenerated successfully using 3D printing, and extended application of 3D bioprinting technique in the field of medicine. Furthermore, information about commercially available 3D printers has also been included in this article.

Keywords 3D bioprinting · Organ transplantation · Organ donor · Decellularization $\cdot$ Scaffold designing $\cdot$ Drug efficacy testing

Arpana Parihar

arpana_parihar@yahoo.com

$\triangle$ Raju Khan

khan.raju@gmail.com

1 Department of Biochemistry and Genetics, Barkatullah University, Bhopal, Madhya Pradesh 462026, India

2 Microfluidics \& MEMS Centre, CSIR-Advanced Materials and Processes Research Institute (AMPRI), Hoshangabad Road Bhopal 462026, India
3 Department of Mechanical Engineering, Indian Institute of Information Technology, Design \& Manufacturing (IIITD\&M), Kancheepuram 600127, India

4 Engineering College Tuwa, At. \& Post. Tuwa, Taluka Godhra, Dist. Panchmahal, Godhra, Gujarat 388713, India

5 Department of Mechanical Engineering, Malaviya National Institute of Technology, Jaipur 302017, India

6 Academy of Scientific and Innovative Research (AcSIR), CSIR-AMPRI, Bhopal 462026, India 


\section{Introduction}

In this world, half of a million patients are estimated on the waiting list for an organ transplant, and due to the inaccessibility of organs, mortality rates increase due to the failure of a vital organ. A deceased donor or a living donor can donate 25 different organs or tissues which can save as many lives as possible [1-3]. Organs such as the kidney, liver, pancreas, lungs and heart, eyes, skin, bone, bone marrow, nerves, brain, heart valves, eardrum, ear bones, and blood can be donated [4-7]. The organ transplantation process seems too easy but identifying a perfect match of the organ is very difficult. Apart from the ethical approval-related hurdles and lack of awareness, organ donation comes with a bag of challenges which include red-tapism and king-sized paperwork. Another challenge is to convince family members for organ donation of their loved ones who are on life support due to deceased or brain-dead situations. Besides this, there are very few hospitals that have equipment for organ preservation and transplantation which further limits the usage of organs of brain-dead patients $[8,9]$. Furthermore, the cost of organ transplantation and medication followed by surgery cannot be afforded by people belonging to low socioeconomic groups or middleincome countries.

Recent advances in the field of tissue engineering and regenerative medicine not only open new avenues to replace and regenerate tissues and organs but also have the potential to correct some birth defects via lab-grown organs and tissue, bioartificial organs, or using xenogeneic organs. Since cells used in regenerative medicine and tissue engineering are taken from the same patient (autologous), therefore the rejection of transplanted tissue/organ via patients' immune system can be avoided, while cells/tissues from another individual (allogeneic) can elicit an immune reaction, which limits their application. However, the immune response can be suppressed by immunosuppressant drugs, but these medicines have several unavoidable side effects. The alternative types of cells from other species known as xenogeneic cells can also be used in regenerative medicine $[10,11]$.

Tissue engineering is the process of creating specific organs by constructing a scaffold out of biomaterials, stem cells, and specific growth factors, which can be implemented using 3D bioprinting, an additive manufacturing technique. This technology is used to create 3D structures by adding material on a layer-by-layer process. This is an industrial fabrication technology that offers rapid and mass production of components $[12,13]$.

In $3 \mathrm{D}$ printing technology tissue or organ, drafting is done by computer-aided software using the specific program which specifically provides instruction to a machine for the generation of 3D scaffolds [13]. However, one of the utmost favorable scaffold designing method is decellularization of organ retaining extracellular matrix (ECM) then recellularization by autologous or stem cells which led to growth and development of the more mature fully personalized organ. The decellularization method removes immune cells, maintaining ECM, and offers equally physical and mechanical microenvironment required by cells to endure and multiply [14-19]. Recently, Alperen Abaci et al. have shown applications of both 3D bioprinting and decellularization technology in developing the appropriate bioink formulation to fabricate $3 \mathrm{D}$ constructs and developing the tissue or organ decellularization methods [16]. Similarly, Kabirian et al. have elaborated the applications of dECM-based bioinks for 3D printing technology [17]. The recent reviews presented the designing dECMbased bioinks $[18,19]$ and their application in 3D printing techniques with limited focus. The present review dealt with the advances in the fields of $3 \mathrm{D}$ bioprinting which includes the 3D bioprinters, their types and specification, process of decellularization, bioink formulation, biomaterial selection, and clinically synthesized and developed 3D organs and tissue. Besides, this current approach for 3D printing technology along with information about commercially available 3D printers has also been discussed.

\section{Current Approach Towards the Tissue and Organ Engineering}

The end-stage organ failure demands the functionally active organ and tissues which are different in structure and function; however, the engineered material could have a similar composition and morphology as the targeted ones. In this context, for developing a functionally transplantable bioartificial organ, certain factors such as type of organ scaffold and method of its sterilization, designing and maintaining of the vascular network of the scaffold, assessment of immunological barriers, type of cells/tissue to regenerate and cells for infusion, functional aspects of the regenerated organ, and route of cell delivery are crucial factors to be considered. Apart from this, assessment of long-term cell survival and engraftment and need for induction factors must be taken into account cautiously $[20,21]$.

\section{Scaffold Designing Approaches}

Scaffolds are used to restore, replace, or regenerate the damaged tissue or organ. Scaffold designing was introduced in the mid-1980s in the field of tissue engineering and since then it continues to grow and evolve as a multidisciplinary field. Scaffolds are mainly made from biomaterials such as polymers, biocomposites, and bioceramics $[22,23]$ which provide the framework for cell attachment and tissue development, cell proliferation, host integration, and vascularization [21]. The successful strategy for designing the scaffolds which includes all features such as biological, mechanical, and 
architectural $[24,25]$ is described in Fig. 1. The scaffolds, which were created using computer-aided design software, must have biomedically relevant design features. As the scaffold provides supporting frame to cells for proliferation and differentiation, therefore, it should be biocompatible and does not provoke immune responses resulting in minimal cell cytotoxicity.

The scaffolds provide mechanical strength and shape to bioengineered tissue. Therefore, biomaterials used for scaffold fabrication should possess good mechanical strength and should be compatible with the shape of the organ to be replaced. Furthermore, the design for the scaffold should be capable of providing enough space for the vascular networks and regeneration of the new tissues. The structure of scaffold should mimic the properties of original body organ and should allow efficient transport of metabolites and nutrients to growing cells/tissues. At the time of implantation, the biomaterial shall be biodegradable at an equal rate to that of a matrix manufacturing by developing tissue. The biomaterial bioink chosen for the fabrication of scaffolds must be biologically active and compatible with the host system; thereby, the engineered tissue actively facilitates and regulates its function. The scaffold may regulate signaling pathways such as the formation of growth factors to speed up the process of regeneration. There are numerous $3 \mathrm{D}$ bioprinting approaches, tools, and biomaterials available to fabricate porous scaffolds with organized porosity and pore sizes such as stereolithography and robocasting [26, 27].

Scaffolds are biodegradable, mechanically robust structures that are effective at transporting metabolites and nutrients. As explained in the previous section, there are various technological approaches to fabricate the scaffolds. The two of them are decellularization and $3 \mathrm{D}$ bioprinting. Decellularization is an alternative way to customize an organ and transplant it without having the host versus graft rejection of an organ [28] which was first described in 2008. The 3D bioprinting is advanced manufacturing technology applied for scaffold production for the generation of complex structures which is used to regenerate damaged tissue. The regenerated tissue via 3D bioprinting has enhanced features such as better permeability, physical and mechanical properties, and fine cellular linkage thereby providing numerous improvements over the established methods [29]. The process of decellularization and 3D bioprinting has been discussed in detail in the following section.

\section{Decellularization: Methods of Whole-Organ Decellularization}

Decellularization is a process of removal of the DNA, lipids, soluble protein, sugars, and other cellular components from tissue. It is a promising and reliable technique that can be applied to any cadaveric solid organ. The schematic process of decellularization is shown in Fig. 2. This process begins with a harvested organ which is recently derived from the brain-dead patient and is placed into a specialized vessel to generate the pale white matrix, i.e., extracellular matrix (ECM) with a complex mixture of structural and functional proteins to preserve structural entities, such as collagen, elastin, glycosaminoglycan (GAG), and fibronectin which function as the scaffold. The matrix can be obtained by employing the decellularization agents which include chemical, enzymatic, and physical methods [30-43].

Decellularization technique has proven potential for organ synthesis in tissue engineering as it keeps alive the 3D structure of organs and ECM (in between which cells are entrapped and are difficult to manufacture). Stripping away the donor's cells causes the removal of antigens that may elicit an immune response and this potentially eliminates the use of corticosteroid treatment.

To build the structural and functional organ, the process of decellularization starts with the procurement of the ECM which can be done in two ways $[44,45]$. Firstly, by culturing the cell in vitro conditions to build the scaffold and secondly,
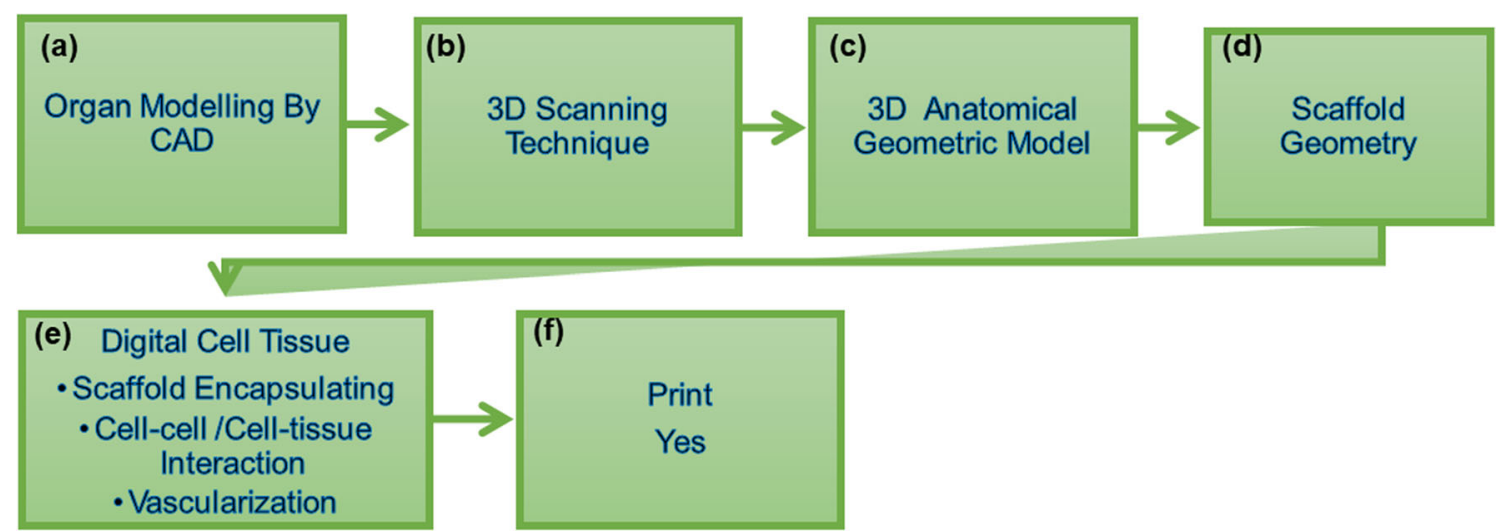

Fig. 1 Flowchart showing steps of scaffold designing: (a) computer simulation and modelling using CAD software. (b) MRI scanning of organ. (c) and (d) Anatomical and geometric designing of 3D structure according to tomographic information. (e) Scaffold fabrication and biomaterial and cell suspension selection (f) print the model 
Fig. 2 Process of decellularization: bioartificial organ development using decellularization and recellularization approach and its probable application

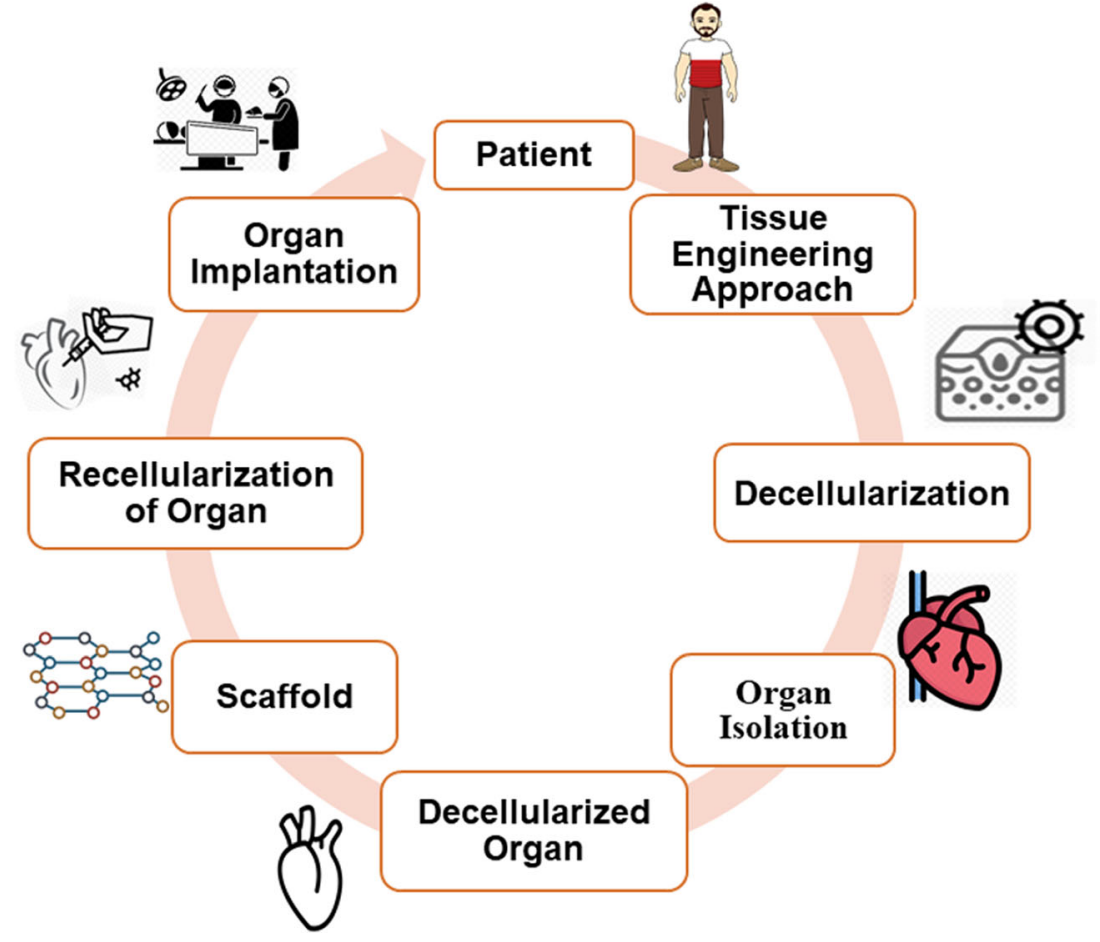

via surgery. While getting scaffold surgically, one should keep in mind some important aspects such as organ age, organ source, sterilization and storage, pressure and temperature, and enzymatic activities. The commonly used decellularization methods are described in Table 1. These methods include the use of detergents, acids, and bases that remove all the native cells and enzymes that can cause rejection during transplantation. Furthermore, after decellularization, i.e., stripping away the donor's cells, the process of recellularization of the decellularized ECM started to produce the structurally and functionally activated organ $[45,47]$.

\section{Recellularization}

The process of recellularization involves repopulating the decellularized ECM with stem cells. Certain factors are crucial for repopulation such as the number of cells, route of infusion, method of infusion, pressure, growth factors, and oxygen supply [47]. As the organ has been recellularized and is ready for the transplantation process, the assessment of recellularized organs is being done which includes steps like determining the functional characteristics, types of cells generated, and most importantly survival rate of cells. After the assessment and repopulation of cells with the recipient's very own stem
Table 1 Techniques used to decellularized tissues and organs

\begin{tabular}{|c|c|c|c|c|c|}
\hline \multicolumn{4}{|c|}{ Decellularization methods } & \multirow{2}{*}{\multicolumn{2}{|c|}{ References }} \\
\hline \multirow{2}{*}{$\begin{array}{l}\text { S. } \\
\text { no. }\end{array}$} & \multicolumn{3}{|c|}{ Types of methods } & & \\
\hline & Enzymes & Trypsin & Endonucleases & Exonuclease & {$[32-34,38]$} \\
\hline 2 & Physical & $\begin{array}{r}\text { Mechanical } \\
\text { Agitation }\end{array}$ & Freeze/Thaw & Sonication & $\begin{array}{l}{[28,32,36,38,} \\
40]\end{array}$ \\
\hline 3 & Chemical & Alkaline/acid & Hypertonic/Hypotonic & EDTA & {$[37,39,42,43]$} \\
\hline 4 & Detergents & Non ionic & Ionic & $\begin{array}{l}\text { EGTA } \\
\text { Zwitterionic }\end{array}$ & {$[28,30,46]$} \\
\hline & & -Triton X-100 & $\begin{array}{l}\text {-Sodium Dodecyl } \\
\text { Sulfate } \\
\text {-Triton X-200 }\end{array}$ & $\begin{array}{l}\cdot \text { CHAPS } \\
\text {-Tri (n-butyl) phos- } \\
\text { phate }\end{array}$ & \\
\hline
\end{tabular}


cells, the generated bioartificial organs have a little or no chance of rejection. The recellularization comprises two major steps: (1) cell seeding in which cells are incorporated into decellularized organ mimicking the in vivo configuration and (2) perfusion culture which involves the preparation of organ or tissue infused with cells for in vivo functions. Cells are repopulated with an acceptable mixture of cells inserted into the scaffold to balance the in vivo cellular structure while cell seeding [48-51]. This method involves either direct infusion of cells into the organ via injection or infusion of cells into the circulation with the expectation that the cells will reach the injury site. Continuous perfusion is performed after the intramural injection of cells or infusion of cells into the vasculature [46, 52]; however, thrombosis limits the cellular repopulation in the ECM scaffolds. In contrast to this, in the perfusion culture method after repopulating the cells, the organ is ready to the perfusate. The perfusate has been selected based on the culture media used in the cell culture of the constituent cell types. By employing this approach, primary goal of viable organ culture can be achieved within few weeks [53-55]. However, certain factors such as difficulty in the procurement of all ECM, immunogenicity, inhomogeneous distribution of cells, organ viability, and age after repopulating it with stem cells, organ structural complexity, and high cost limit the application of this method.

\section{D Bioprinting}

Bioprinting is a layer-by-layer additive fabrication process that uses living cell suspension instead of thermoplastic or resin to create three-dimensional structures. In the pharmaceutical industries and tissue engineering, to construct 3D structure, the bioink or biomaterials which contain cells and growth factors is layered from bottom to top [56]. Recent advances in 3D bioprinting have the potential to meet the demands of tissues and organs for transplant by printing them. The steps involved in the 3D bioprinting process are presented in the schematic shown in Fig. 3. The first step is to model the 3D structure of tissue or organ using a computer modelling program followed by printing with bioink producing 3D structures. Subsequently, post-processing and assessment of the physical, mechanical, and biological function of 3D-printed tissue have been carried out before transplanting the printed organs or tissue in the patients. The 3D bioprinting can be used as potential approach to meet the demand of organs for critical human organ transplantation cases [57].

The 3D printing technique was first developed in the 1980s using computer-aided software (CAD) to develop 3D structures; however, the organ and tissue printing evolved in later stage. More recently, the 3D bioprinting method has grown as multidisciplinary technology converging various areas such as bioinformatics, chemistry, mathematics, computer sciences, medicine, material sciences, biological sciences, and industrial designer which makes this widely applicable. 3D bioprinting is rapid and a manufacturing technology that is used to fabricate the complex shape with precision and this process builds this architecture layer by layer [58]. 3D printing involves complex protocol to be processed as it includes the additional planning for printing multiple cells, including the printing of vasculature and neural network for actually developing the fully functional 3D bioprinted organ $[59,60]$.

In this technique, bioprinter-type, bioink selection, celltype, nozzle-type, 2D, and 3D imaging of the organ, modeling, and designing of organ/tissue and microenvironment for culture must be chosen properly for better printing of tissue [56]. The biofabrication of tissues and organs in a stratified manner is divided into three steps: (a) pre-bioprinting (modeling), (b) bioprinting, (c) post-bioprinting (maturation and assessment), which is shown in Fig. 4.

In the pre-bioprinting process, the appropriate biomaterial has to be selected first for the organ that the printer is supposed to be created. For this, the 3D imaging and biopsy of the targeted organ or tissue have been performed using technologies like 3D scanners, CT, and MRI. This 3D imaging provides tomographic and architectural information. Based on these 3D images, computer-aided software generates a 3D structure of the organ. Followed by this, the specific bioink (biomaterial) was selected based upon the type of bioprinter and the properties of the targeted tissue [61]. Selecting the
Fig. 3 Hierarchical procedure of designing, printing, and postprinting assessment

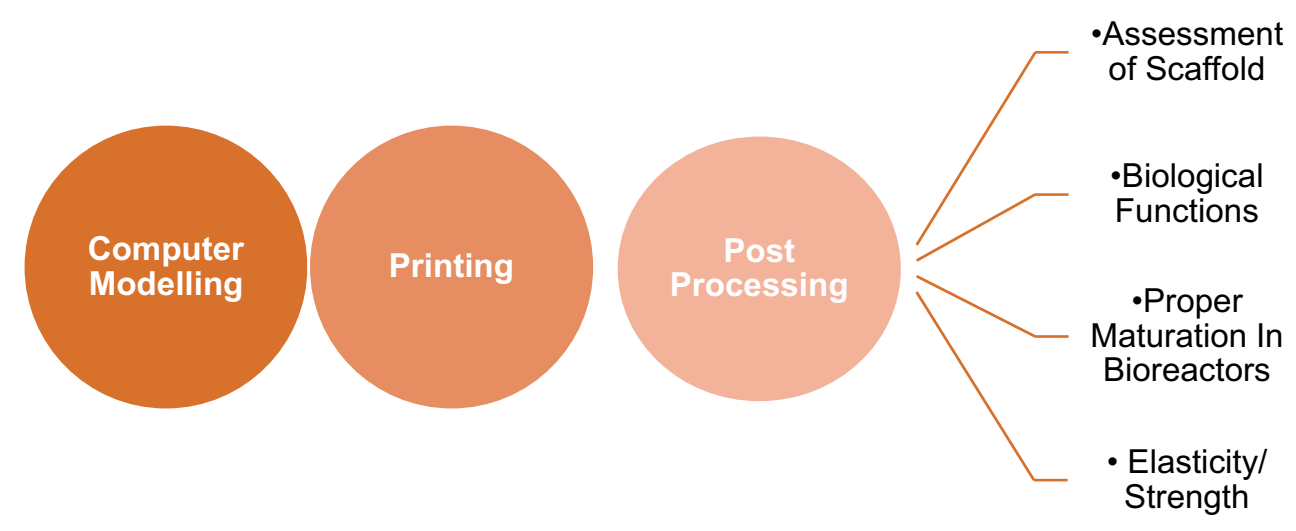


Fig. 4 Steps In 3D bioprinting: different steps and stages that lead to the production of bioprinted constructs for implantation or in vitro testing
Pre-processing (Pre-bioprinting)

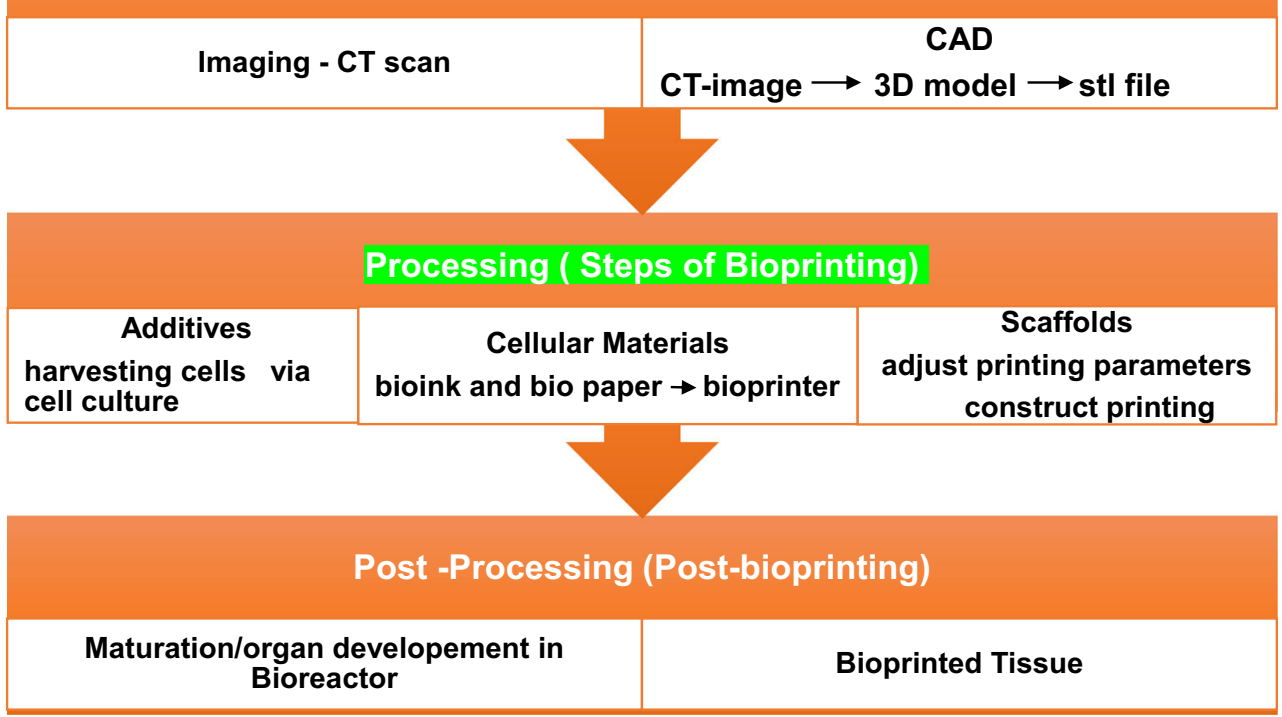

cost-effective suitable biomaterial that could provide both physical and mechanical strength is a crucial step. Furthermore, the bioprinting process requires a 3D design of the organ, cells specific to the patient, and an appropriate bioink. Initially, the 3D design, cells, and bioink are directly loaded to the printer which is followed by layer-by-layer deposition of the cells. The printer gradually deposited layers of liquid, cells, and other required material to create the 3D structure of the organ as per command given by the software which generally recognized "STL" file format. The printer is equipped with nozzles consisting of multiple biomaterials inks, at adjustable angles [56-63]. Bioprinting can be divided into two parts: cellular bioprinting and acellular bioprinting. Cellular bioprinting is a technique that involves the fabrication of tissue with living cells. Based on printing, i.e., deposition of bioink the cellular bioprinting is further divided into 3types: droplet-based, extrusion-based, and stereolithography. In the case of the acellular bioprinting method choice of various types of bioink for a bioreactor to obtain the cells, seeding is available. This is further divided into two types: extrusionbased acellular bioprinting (EAB) and laser-based acellular bioprinting (LAB). The types of cellular and acellular bioprinters have been discussed in the subsequent section of this review.

The post-bioprinting stage involves the maturation of printed organs which includes the development of the neural networks, extracellular matrix (support mechanically), and natural functions. After this, the bioprinted organ is further assessed through bioreactors that are required for creating higher mechanical elasticity of the tissue, assessing biological functions, and an accurate scaffold that is completely ready for in vitro usage [56,57]. Post-processing steps are performed on the final product that includes removing the unconsumed fragments, cooling, drilling, cutting, polishing, and sterilization. Also, the end products are being tested to make sure the product has appropriate characteristics or traits that include all its functional properties and strength $[64,65]$.

\section{Type of 3D Printers}

As mentioned in previous section, 3D printing is an automated method that can be explored for modelling and designing complex 3D structures (outer geometry, pore, and internal connecting vessels) by using $3 \mathrm{D}$ bioprinters. The scaffolds and extracellular matrix along with specific biomaterials are used as precursors for printing organ. In this technique, in vivo environment under in vitro conditions has been provided by simply mimicking the situations [66]. The schematic in Fig. 5 shows types of 3D printers. In this article, we will discuss commonly used 3D printers which include microextrusion printers, laser-based printers, and inkjet printers. The specific features such as resolution, speed, volume, stability, the viscosity of bioink, bioink type, cell density, and cost of five different types of bioprinting techniques are discussed in Table 2.

\section{Extrusion-Based Bioprinting}

This technology is rapidly expanding and has made significant growth in the last few decades. In this method, 3D printing is done by exerting the mechanical pressure, and the bioink is extruded out through the heated nozzle onto the printing bed $[66,67]$. These types of printers are used for printing various structures including cells, tissues, tissue constructs, modules, and microfluidic devices. Despite of several advantages and 
Table 2 Specific features such as resolution, speed, volume, stability, the viscosity of bioink, bioink type, cell density, and cost of five different types of bioprinting techniques

\begin{tabular}{|c|c|c|c|c|c|c|}
\hline Characteristics & Inkjet & Extrusion & Laser-assisted & Stereolithography & $\begin{array}{l}\text { Fused deposition } \\
\text { modelling }\end{array}$ & Reference \\
\hline Resolution & $50-300 \mu \mathrm{m}$ & Wide range & $\begin{array}{l}\text { Microscale } \\
\text { resolution }\end{array}$ & High & Low & {$[21,23]$} \\
\hline Speed & $\begin{array}{l}\text { Fast } \\
\left(1-10,000 \text { droplets } \mathrm{s}^{-1}\right)\end{array}$ & $\begin{array}{l}\text { Slow }(5 \mathrm{~mm} \\
\left.\mathrm{s}^{-1}\right)\end{array}$ & 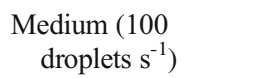 & Slow & Fast & {$[32]$} \\
\hline $\begin{array}{l}\text { Volume (capacity of } \\
\text { bioink storage) }\end{array}$ & $\mathrm{ml}$ range & $\mathrm{ml}$ range & $>500 \mathrm{ml}$ & $\begin{array}{l}\text { Up to } 300 \times 335 \times \\
200 \mathrm{~mm}\end{array}$ & $\begin{array}{l}\text { Up to } \sim 200 \times 200 \times \\
300 \mathrm{~mm}\end{array}$ & {$[23,31]$} \\
\hline Stability & Poor & Good & Fair & Good & Fair & {$[35,36]$} \\
\hline Viscosity of bioink & $3.5-12 \mathrm{mPa} / \mathrm{s}$ & $\begin{array}{l}\text { up to above } \\
\qquad 6 \times 10^{7} \mathrm{mPa} / \mathrm{s}\end{array}$ & $1-300 \mathrm{mPa} / \mathrm{s}$ & No limitation & $5 \mathrm{mPa} / \mathrm{s}$ & $\begin{array}{c}{[32,35,} \\
36]\end{array}$ \\
\hline Bioink type & Cell suspension & $\begin{array}{l}\text { Viscous } \\
\text { materials }\end{array}$ & $\begin{array}{l}\text { Cell suspension, } \\
\text { Viscous materials }\end{array}$ & $\begin{array}{c}\text { Photosensitive } \\
\text { Resins }\end{array}$ & $\begin{array}{l}\text { Thermoplastics such } \\
\text { as PLA, PLLA, } \\
\text { Nylon, PCL, PLGA }\end{array}$ & {$[37,38]$} \\
\hline Cell density & Low $\left(<10^{6}\right.$ cells ml- 1$)$ & $\begin{array}{l}\text { High (cell } \\
\text { spheroids) }\end{array}$ & Medium & $\begin{array}{l}\text { Medium / no lim- } \\
\text { itation }\end{array}$ & low & {$[31]$} \\
\hline Cost & Low & Medium & High & High & Low & {$[28,29]$} \\
\hline Specific characteristic & $\begin{array}{l}\text { Materials used are low cost; } \\
\text { contactless sterile printing }\end{array}$ & $\begin{array}{l}\text { Commercially } \\
\text { available }\end{array}$ & Compatible & Limited material & Limited material & $\begin{array}{l}{[25,26} \\
31,32]\end{array}$ \\
\hline
\end{tabular}

great versatility in printing the various $3 \mathrm{D}$ structures, many questions and restrictions are being raised such as organ fabrication and low resolution of printed features [68, 69].

\section{Microextrusion Printing}

This printing technique is based upon the principle of extrusion, i.e., it uses force to selectively divide the biomaterial and cells via nozzles and needles with the application of heat [67]. Microextrusion bioprinters usually consist of a temperature-controlled biomaterial dispensing system which generates a constant string of bioink rather than many droplets of bioink by applying pressure (pneumatically or mechanically). A microextrusion printer consists of numerous nozzles for each material to be used for designing the architecture, but certain factors should keep in mind such as enough space between the nozzles, speeds, diameter of the nozzle, and the mechanical force to inject material via the piston. Furthermore, the viscosity of bioinks used in the printer must be appropriate, as it maintains the architecture of the scaffold and prevents it from collapsing while maintaining the highresolution printing Fig. 6.

\section{Inkjet Printers}

This technique is based on the working of general 2D printers. This printing technique involves the heating principle. In this, a piezoelectric actuator vaporizes the cell suspended liquid into bubbles which can escape through a nozzle in droplet form from chosen position [70]. It has high printing speed but due to the use of a piezoelectric actuator, the cells come in direct contact with the heat, which results in cell membrane damage and cell lysis. However, the inkjet bioprinting technology can hasten the study of tissue biofabrication [71]. There is remarkable success in the invention of bioinks and biopapers that are appropriate for inkjet bioprinters. This technology allows the printing of complicated organs and tissue
Fig. 5 Hierarchy chart of bioprinting techniques: (A) First division shows the types of bioprinting techniques. (B) Second division depicts the type of printers

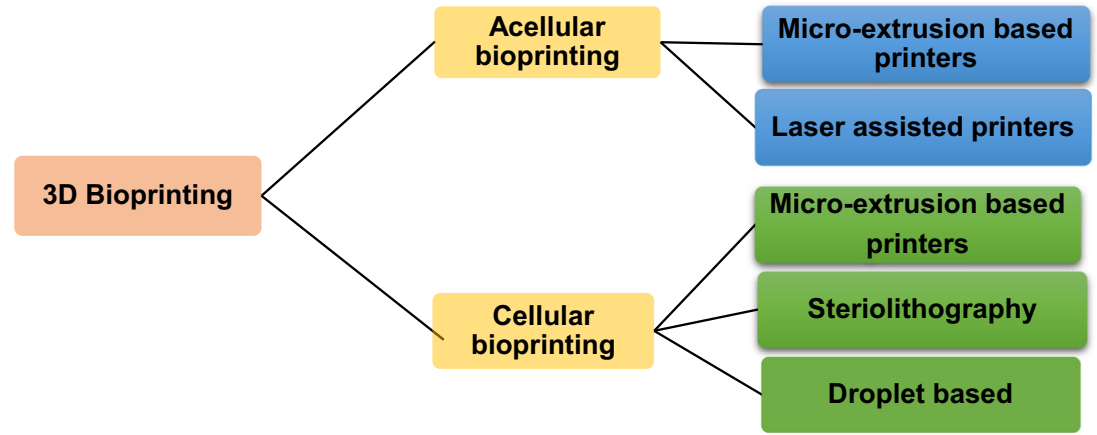




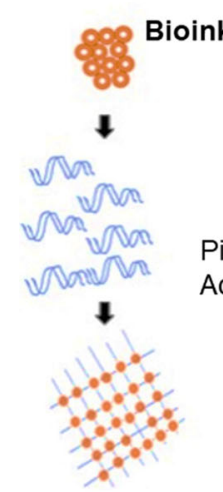

(a)

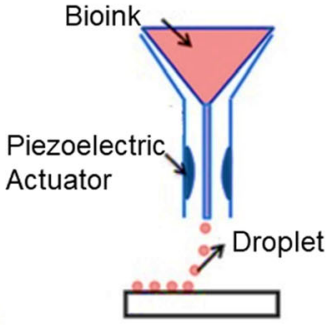

(b)

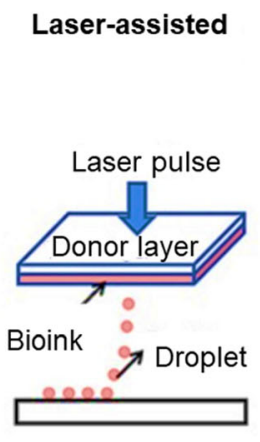

(c)

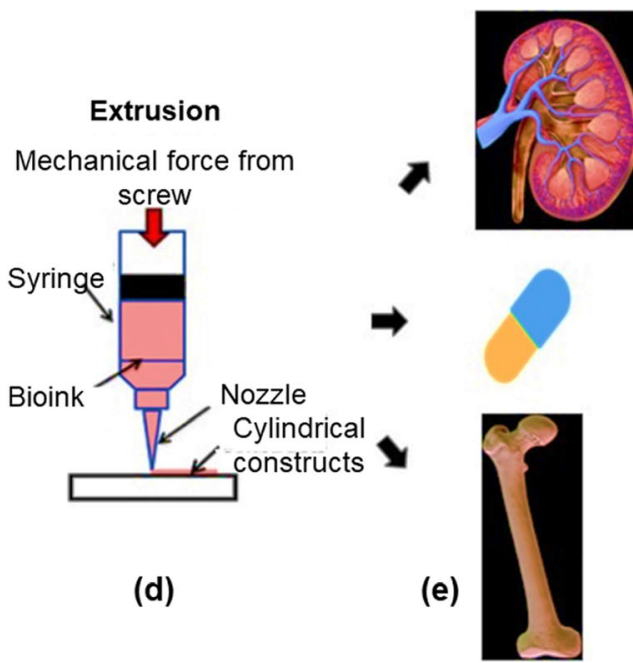

Fig. 6 Type of bioprinting approaches and their working methods. (a) Workflow of designing the bioink for printers involves the living cell suspension and biomaterials. (b) Inkjet-based printing extrudes out the fractions of molecules of bioink. (c) Laser-based bioprinting involves the use of laser focused on absorbing layer, high gas pressure generated by

with accuracy by using the cells as bioinks, although it has limitations such as large organs cannot be printed properly and the droplet size cannot be controlled. However, it is a muchpreferred technique over microextrusion technique as it provides enhanced resolution of droplets and exhibits great cell viability [72].

\section{Laser-Based Printers}

This printing technique uses lasers for designing the architecture of the tissue. The use of lasers provides the droplets with high resolution. Initially, the laser is focused and bioink is cast on the substrate or printing bed. The laser beam gets activated immediately after striking the absorbing layer, the laser impacted area evaporates and the high gas pressure induces the bioink onto the printing bed, and finally, the scaffold is made layer by layer. The laser printers are advantageous when compared to microextrusion and inkjet printers as it uses less force and minimum heating while printing the tissue [73].

\section{Stereolithography Bioprinting}

This is the oldest approach for bioprinting 3D structures with high resolution and precision [74]. This bioprinting technique produces complex 3D structures by frequently layering on 2D-lined layers afterwards the photo-polymerization of 2D patterned layers is considered to be the most crucial step in this bioprinting [75]. The models and fabricates made with this technique are well-built and can be used to make master models for various metal casting processes [75-77]. This

affected area induces the bioink onto the printing bed; (d) Extrusionbased bioprinting uses mechanical pressure to frequently extrude out bioink (cell-polymer solution).finally, the scaffold is made layer by layer. (e) The medicinal approach in tissue engineering, drug testing, and designing for in vitro study model for disease diagnosis

technique is costly and the photopolymers used in this technique need to be handled with care as they are more viscous $[78,79]$.

\section{Droplet-Based Bioprinting}

Droplet-based bioprinting technology is all-purpose technology as it offers higher resolution and allows the better regulation of geometry and size of bioprinted 3D structures. This technology possesses greater resourcefulness in various fields of studies that attracted many researchers to use this technology in the field of bioprinting [80, 81]. Its affordable commercial availability and versatility [82] make it the technique of choice. However, a small diameter of the orifice of this printer causes the clogging of the orifice during the bioprinting and the bioink keeps accumulating within the orifice and results in obstruction of flow which limits its application. Due to this reason, instead of bioinks, hydrogels and other biomaterials are used for constructing the structures [83]. Besides this, droplet-based bioprinter fails to assemble mechanically strong and structurally unified constructs due to the restricted selection of biomaterials [84]. Moreover, despite the high resolution of droplet-based bioprinter, it is a much timeconsuming technique that sometimes results in swelling of the tissue structure $[85,86]$. Among all the 3D bioprinters described above, laser-assisted or laser-based bioprinters are more successful and widely used to fabricate organs and tissues [73]. Unlike extrusion, microextrusion, and inkjet printers, these 3D bioprinters do not use a nozzle to dispense ink; instead of this, they use a direct UV light on the printing bed of bioink which gets hard when exposed to light. 


\section{Bioinks: the Building Material}

Additive manufacturing technologies-based 3D bioprinting techniques have made significant progress in recent years for the development of complex geometry. In this process, selection of appropriate bioink, cells, and biomaterials for the effective fabrication of targeted tissue plays crucial role. The successfulness of the fabrication depends upon properties such as solidifying kinetics of the biomaterials and the native, chemically, or environmentally induced material properties [87]. A suitable bioink material should provide the growth factors, adhesion factors, signaling proteins, and mechanical and structural properties of ECM. These are the progressive events that promote a suitable environment for cell survival, viability, and differentiation [88]. The conventional techniques used were not able to build structures with the expected interest and desires. While modeling organs and tissues, bioink, biomaterial, and cells should be selected appropriately that resemble the tissue intended to be reconstructed to develop inevitably correct biological structure. The major types of bioink materials used for printing are cell-scaffold-based bioprinting and scaffold-free bioprinting. In the cell-based bioprinting approach, the bioink consists of biomaterials incorporated with the cell suspension to build the 3D construct of tissues and organs. Furthermore, the scaffold gets degraded and cells proliferate and occupy the space to form predesigned tissue structures whereas in scaffold-free bioprinting, the bioink only consists of cell suspension. Here, the cells are programmed to behave like embryonic stem cells, which further get arranged in a specific manner to perform some specialized functions [89-93].

\section{Biomaterial Selection}

The biomaterial selected for 3D printing of tissue construct should be affordable, commercially available, and convenient for clinical purposes. Furthermore, it should be biocompatible with the biological system; therefore, it cannot elicit the immune response and provide an environment for cell survival, motility, and differentiation. Besides this, biomaterial must have suitable physicochemical properties which should meet the demands of the printer [94-96]. The hydrogel, ceramic, polymers, and composites are some excellent examples of currently used biomaterials for 3D printing. Hydrogels are the most widely used biomaterial ink for the bioprinting of the organ as it provides temporary support to cells while they produce their own ECM. These are water-swollen, crosslinked polymeric structures produced by the simple reaction of one or two monomers. The hydrogen bonds and Vander Waal interaction are generally involving in cross-linking between the chains. Hydrogel is suitable for all types of printer inkjet, laser-based, microextrusion. Hydrogels can be formed using three types of polymers: natural such as cellulose, fibrinogen, gelatine, collagen, and agar; synthetics such as polyethylene glycol, and polyacrylamide; or syntheticnatural mixture. Hydrogels are commonly used for bone regeneration or bone defects coating with hydroxyapatite, carbon nanotubes [94, 95]. Ceramics are also used frequently as biomaterials for printing because of their unique properties such as hardness, brittleness, and chemical inertness. Most importantly, ceramics are biocompatible and have a similar composition as bones. Ceramics are generally used in inkjetand particle-based bioprinters which convert the powder into suspension form. In powder bed-based printers, the ceramic powder of appropriate size (diameter 10-150 $\mu \mathrm{m}$ ) and proper particle flow within the bed is used. However, for inkjet printers, apart from particle size, viscosity, and solid content of ceramics, biomaterials should be appropriate. Ceramics are used for the replacement of hips, knees, teeth, tendons, and ligaments. Also, it is commonly used by doctors for facial and maxillofacial reconstruction [97, 98]. Hydroxyapatite-based ceramics are highly bioactive and biocompatible materials and have a similar composition as bones. Certain polymers are also used in bioprinters due to their low cost and other suitable properties such as biodegradability, flexibility, good mechanics, and biocompatibility. Polymers are easily manufactured by printers and can be transformed into any desired shape. Generally, polymers are used by dentists and pharmacologists for drug delivery and targeting sites of inflammation or tumors $[91,92]$. Some composites are also used as bioinks due to their excellent properties such as bioactive, stiffness, and printer compatibility. The most commonly used composites for the printers are biomolecules, carbon nanotubes, and some metal and alloys [97].

\section{Selection of Cell Lines}

Multiple cell types which are structurally and functionally specific generally constitute an organ or tissue and all these cells exhibit regenerative capacity. Therefore, while selecting the cells for the organ printing, certain factors should be kept in mind such as the cells must have appropriate proliferation and differentiation capacity in printed scaffolds along with the ability to involve in the signaling cascade. Furthermore, the cell survival and viability during and after the printing procedure are crucial factors; hence, enough cells should be cultured and taken for the printing process. Cellular functions should be checked and maintained in in vitro as well as in vivo environments [98].

For 3D printing of desired tissue construct and organ, bioink, biomaterials, and cells should be chosen wisely keeping all the above-mentioned crucial factors in mind. Several organs have been successfully printed and transplanted in patients listed in Table 3. Table 3 discusses the organs printed by a different type of $3 \mathrm{D}$ printing technique and the types of bioink used for the printing 
Table 3 Different 3D printing technique for bioprinting of various organ and tissues

\begin{tabular}{|c|c|c|c|}
\hline $\begin{array}{l}\text { Target organ/ } \\
\text { tissue }\end{array}$ & Printing technique & Bioink & References \\
\hline \multirow[t]{3}{*}{ Skin } & Droplet/inkjet & i Cell suspended media for printing cells & [99-102] \\
\hline & & ii Collagen solution for printing the supportive layer & \\
\hline & Laser assisted & $\begin{array}{l}\text { iii Hydrogel } \\
\text { Matriderm }\end{array}$ & \\
\hline \multirow[t]{4}{*}{ Liver } & Inkjet & i Cell suspended media for printing cells & {$[103-105]$} \\
\hline & & $\begin{array}{l}\text { ii Fibronectin gelatine solution for printing adhesive } \\
\text { film between monolayer }\end{array}$ & \\
\hline & Stereolithography & Gelatine methacrylate for printing hiPSC & {$[106]$} \\
\hline & Extrusion & Hepatocyte aggregates & {$[107]$} \\
\hline \multirow[t]{8}{*}{ Bone } & Extrusion-based rapid & Natural and synthetic polymers solution & {$[108]$} \\
\hline & EBM & & \\
\hline & Prototyping (RP) & & \\
\hline & $\begin{array}{l}\text { Fused deposition } \\
\text { modelling (FDM) }\end{array}$ & $\begin{array}{l}\text { Synthetic polymers, such as acrylonitrile butadiene } \\
\text { styrene (ABS), polylactic acid (PLA), }\end{array}$ & {$[109]$} \\
\hline & & Polyvinyl alcohol (PVA) & \\
\hline & SLA/SLM & PPF/DEF-HA, PDLLA/HA, $\beta$-tricalcium phosphate & [108-112] \\
\hline & Binderjetting, EBM & $(\beta-\mathrm{TCP})$ & \\
\hline & $\begin{array}{c}\text { Laser-assisted } \\
\text { bioprinting }\end{array}$ & $\begin{array}{l}\text { HA, Zirconia, HA/MG63 osteoblast-like cell, nano } \\
\text { HA, human osteoprogenitor cell, Human umbilical } \\
\text { vein endothelial cell }\end{array}$ & [112] \\
\hline \multirow[t]{2}{*}{ Cartilage } & Pneumatic & Natural polymer solutions, such as alginate and & {$[113,114]$} \\
\hline & Extrusion based & $\begin{array}{l}\text { proteins, cells, and growth factors can be } \\
\text { incorporated }\end{array}$ & \\
\hline \multirow{6}{*}{$\begin{array}{l}\text { Ear } \\
\text { craniofacial }\end{array}$} & Extrusion-Based -Rp & Natural or synthetic polymers solution & {$[115]$} \\
\hline & Direct write RP & $\begin{array}{l}\text { A concentrated colloidal gel (typically } 50 \% \text { of HA in } \\
\text { an aqueous medium) }\end{array}$ & [116] \\
\hline & Stereolithography & Polypropylene & {$[116,117]$} \\
\hline & Inkjet & PEEK, PLA, PLGA. & {$[117]$} \\
\hline & Extrusion (EBM) & Fibrinogen, Gelatin, Alginate & {$[117,118]$} \\
\hline & FDM & Titanium, PCL & {$[118]$} \\
\hline $\begin{array}{l}\text { Trochlea } \\
\text { (rabbit) }\end{array}$ & $\begin{array}{l}\text { Indirect } \\
\text { microstereolithogra- } \\
\text { phy }\end{array}$ & $\begin{array}{l}\text { Poly- (L-Lactide- } c o-\varepsilon- \\
\text { caprolactone)/gelatine, heparin, } \\
\text { transforming growth factor beta } 1 \text {, chondrocytes }\end{array}$ & [119] \\
\hline Bone defects & $\begin{array}{l}\text { FDM (fused deposition } \\
\text { modelling) }\end{array}$ & Hydroxyapatite incorporated polycaprolactone & {$[111,120]$} \\
\hline $\begin{array}{l}\text { Endothelial } \\
\text { progenitor } \\
\text { cells }\end{array}$ & $\begin{array}{l}\text { Binderjetting, EBM } \\
\text { Thermal inkjet-based } \\
\text { AM }\end{array}$ & Collagen solutions & {$[121]$} \\
\hline Breast cancer & Extrusion & i Breast cancer cell aggregates & {$[122]$} \\
\hline $\begin{array}{l}\text { Cervical } \\
\text { cancer }\end{array}$ & Extrusion & $\begin{array}{l}\text { ii Stromal cell aggregates } \\
\text { Gelatine -alginate-fibrinogen solution for printing } \\
\text { cells }\end{array}$ & {$[123]$} \\
\hline
\end{tabular}

process. Printed tissues can be of two types: soft tissue such as muscles, tendons, ligaments, nerves, blood vessels, synovial membrane, skin, and fascia, and hard tissue such as bones, tooth, cartilage, and enamel. The hard organs for instance artificial limb, bladder, brain, testis, eye, lungs, ovaries, pancreas, trachea, thymus, heart, kidney, liver, and ear can also be printed successfully using this technology.

\section{Applications of 3D Printing Techniques}

Organs generated by 3D printing technologies enable patient's recovery faster and more efficiently. Recent advances in the field of 3D printing have gained considerable attention as it can suffice the need for organs that cannot only improve the quality of life of patients but also save lives in many cases. Besides organ printing, the $3 \mathrm{D}$ printing technology offers 
extended medical applications such as synthesis of prosthetics, drug screening, testing, and manufacturing of goodquality cosmetics. Notably, this technology can help generate personalized medicine for the cure of specific disorders in patients. Personalized medicine reduces the possibility of adverse effects due to these dosages outside the therapeutic window or subtherapeutic benefits.

\section{Clinical Application for Organ/Tissue Printing}

The bioprinting process utilizes the patient's cell for constructing the fully functional three-dimensional tissue construct by assembling cells layer-by-layer by using biocompatible scaffolds which when incorporated with living cells regenerate functional tissue.

The computer-aided design software has been used for effective $3 \mathrm{D}$ bioprinting to build the $3 \mathrm{D}$ constructs. All the processes in this technique such as position and speed of printing nozzles, and deposition of cells and materials are strictly controlled by the software. Some of the examples of organs generated by the 3D printing technique are listed in Table 3. However, this technology can be used to create all types of organs or tissue and some of the successful 3D printed organs are as follows

Skin Bioprinting The imminent solution to burn wound reconstruction is the utilization of artificial skin which can cure the skin of third-degree burns $[124,125]$. The third-degree burns or secondary burn injuries required surgical ablation of damaged skin and replacing it with the traditional and accepted skin which can be successfully achieved by stratified $3 \mathrm{D}$ bioprinting technique. In this process, desired scaffolds are incorporated with living cells over the burn parts, which heals the burn via the formation of healthy skin tissue. In this regard, clinically convenient broadspectrum skin substitutes are available, e.g., Matriderm ${ }^{\circledR}$, Integra ${ }^{\circledR}$, Dermagraft $\AA$, and $\left.\mathrm{OrCel} \circledast\right)$ ] $[126,127]$. To construct the bioprinted skin, multiple cell types and biomaterials are preferred. Initially, the scaffold of dermal and epidermal skin is incorporated with keratinocytes and fibroblast; after that, they are cultured at a liquid interface that gives rise to the skin appearance. The melanocytes are generally printed between the layers to have a complete biometric skin [99-103, 128]. In a recent study, bioink is prepared by mixing silk protein with gelatine and then blended with specific skin-forming cells [102]. However, certain skin appendages like sweat glands, melanocytes, endothelial cells, hair follicles, and sebaceous glands in the skin are still troublesome to create. Despite this fact, artificial skin developed by the 3D printing technology has proven effective in wound healing and is also used in various pharmaceutical companies and chemical testing researches [103].
Hepatic Tissue Bioprinting Liver injury and hepatic diseases such as fatty liver and hepatitis have increased the demand of hepatic tissue bioprinting [104]. Nguyen et al. have bioprinted 3D primary liver tissues that facilitate the evaluation and testing of organ level response of drug [105]. In another study, Chang et al. biofabricated micro-3D liver organ, which can be explored as in vitro drug testing and to study metabolism [129]. A simple one step fabrication approach of an organon-a-chip using $3 \mathrm{D}$ printing has been described by Lee et al. [106]. A liver-on-a-chip platform with bioprinted hepatic spheroids has been demonstrated in another study [107].

Cartilage Bioprinting Cartilage tissue is a type of elastic connective tissue; if it gets damaged, it is incompetent to reconstruct on its own and therefore it is surgically restored by a substitute. However, artificial substitutes failed to heal naturally which causes cartilage lesions [113, 114, 130-132]. In 3D printing, cartilaginous tissue scaffolds are incorporated with bioink such as chondrocytes, mesenchymal stem cells, and bone marrow cells which led to the generation of desired tissue $[113,132]$. Certain limitations like weak mechanical strength and firmness of the implanted cartilage tissue raised concern. Nevertheless, 3D bioprinting shows great applications in cartilage tissue repair as it promises to mimic the exact in vivo environment of cartilage tissue. A group of researchers in Sweden successfully introduced 3D printed human cartilage into mice [132]. They printed a hydrogel of nanocellulose mixed with human-derived cartilage cells, then surgically implanted the structures into mice. Once implanted, new blood vessels formed within the printed cartilage.

Kidney The kidney is one of the most difficult organs to be constructed by $3 \mathrm{D}$ printed technology because of its complex structure $[133,134]$. The bioinks consisting of kidney cells and surrounding materials for printing kidneys have been used in this context. The bioink has the thickness of a toothpaste that can be expelled at room temperature and enables the building of complex structures. This research group has been able to rejuvenate the nephron, the operational unit of the kidney which can conduct filtration and reabsorption of useful components. Besides this, several alternative organs also named grafts, prostheses, implants, analogs, and precursors, and these are clinically part of regenerative medicine and are successfully generated using this technology.

There are several case studies in which 3D printed organs were transplanted successfully. A patient with spina bifida (a condition where a part of the spinal cord has grown outside the spinal column) had bladder outgrowth which results in urine leakage that affects the kidney. In this case, the patient's healthy cells were used to make up the urinary tract and bladder [134]. In another case, 3D printed medical model company along with surgeons at Belfast City Hospital in Northern 
Ireland created a 3D printed replica of the kidney which works fine [135].

The Heart The heart is the easiest organ to be printed as it does not have a complex structure and its primary function is to pump blood [136, 137]. For heart tissue printing, initially, the donor's heart is scanned with CT and MRI machines which find out the structure and size of the heart. Afterward, the patients' blood cells are collected and converted into stem cells under the influence of growth factors which regenerates the heart cells using bioink mixed with hydrogel in 3D printers [136-139]. Here, the bioink is being stratified onto a scaffold that provides mechanical support and the exact shape of the patient heart where cells grow and proliferate. After a few days, cells start to join and begin to beat like an original heart. The scaffold is now removed and the heart is ready to implant. The person's stem cells are used to reconstruct the organ which reduces the chances of host versus graft disease and there would be no need for immunosuppressant drugs. A biotech start-up company BioLife4D constructed a miniature heart for testing in small animals [138]. A group of researchers from Carnegie Mellon University developed a new method for $3 \mathrm{D}$ bioprinted tissue scaffolds out of collagen and this new technique allows to $3 \mathrm{D}$ print a full-sized, adult human heart [140]. In another report, when the 3D bioprinted heart incorporated with human cells, the heart does not beat as it was too small; it was only about the size of a rabbit's heart, too small for a human [141].

Bones The new method "Nanokicking" was developed to grow 3D constructs of mineralized bones by researchers of the University of Glasgow. They used stem cells from the human donor and turning them into the 3D bone graft and this bone graft was implanted into the dog's leg. It is expected that this $3 \mathrm{D}$ bone graft work would be ready to transplant in humans by the end of 2020 [108, 110].

In a similar report, based on a CT scan of the patient, engineers design the 3D printed bone implants together with the surgeon which can fit perfectly in place. The process showed promising results but it is still in the testing phase [109]. The pre-clinical study showed that, within 24 weeks, the implant fused with the patient's bone started rejuvenating and marrow was beginning to form in the transplant [112]. Moreover, 3D printing of bone tissue using different compatible biomaterials has been carried out successfully [116-121].

\section{Drug Screening and Testing}

3D printing enables the quick production of customized models and manufacturing of complex structures with different geometries. The technology offers drug production and customization that is personalized-dose medicines, sophisticated and complex dosage forms, on-demand manufacturing, and the development of drug delivery systems with nontraditional geometries for pharmaceutical drug testing applications (e.g., drug-eluding implants) [122, 123, 142-146]. The first time 3D printed tablets gained US FDA approval was in 2015; since then, 3D printing of drugs is expected to increase in the pharmaceutical industry and pharmacy practice [147]. The in vivo assessment through bioprinting is quick and easy. Furthermore, the customization of the drug can be regulated as the matrix properties, porosity, and shape could easily be manipulated by using different material choices used for printing the scaffold that affects cell adhesion. Therefore, bioprinting demonstrated huge potential in drug discovery and preclinical testing due to its high speed, precision, and consistent reproducibility [148].

Recently, researchers have successfully used mini tissue, organ-on-chip, and tissue constructs for in vitro drug screening [149-151]. 3D mini-tissue models can be constructed through common 3D bioprinting techniques based on various cell sources and biomaterials [152-154]. 3D mini-tissue models facilitate high-throughput testing in case of cancer disease which can provide predictive or prognostic information. However, the drug screening in 2D cell culture models are easy to manipulate but it lacks the in vivo microenvironment and therefore one cannot predict its full efficacy. In this context, the 3D printed tissue models and organ-on-a-chip mimic the complex microenvironment of human tissues and therefore drug testing efficacy can be predicted more accurately $[155,156]$. Jalili-Firoozinezhad et al. investigated the efficacy of radiation countermeasure drugs by using a gut-on-achip model. This model consists of epithelial and endothelial cells and cyclic suction was applied to mimic the stress felt during physiological peristalsis movement by cells. Under controlled conditions, epithelial cells undergo villus differentiation, similar to that inside the human body [156]. However, a more personalized approach is needed for drug screening and testing with strict standardization and quantification requirements [157-160] which can be resolved by introducing ECM mimicking materials in tissue/organ construct. The organ-on-a-chip models produced using a tissue engineering approach have the potential to be perfect models for drug testing. It involves incorporating the cells into scaffolds and allowed to grow which created a functional construct that can be used to replace/repair damaged tissues or organs [158]. These models have the potential to replace animal models that are used for drug response and toxicology screening. By reducing the number of animals used in preclinical studies, the cost of drug development can be reduced, and also the ethical issues regarding laboratory animal usage for drug testing and screening can be compensated.

Recently, several efforts have been made to construct the tumor microenvironment of various cancers including cervical cancer and triple-negative breast cancer with fibroblasts using $3 \mathrm{D}$ bioprinting technologies [158-160]. The tumor 
microenvironment thus created was used to study the effect of drugs on the stromal cells in cancer [160]. Langer et al. bioprinted a heterotypic tumor microenvironment that consisted of patient-derived cancer cells, fibroblasts, and endothelial cells, which closely mimic in vivo tumor microenvironment [161].

\section{COVID-19 Testing and Shortage Supply}

COVID-19 was first detected in China on December 19 causing an expanding and accelerating health crisis around the world. This pandemic has placed massive stress and a huge gap in demand and supply chains in terms of diagnostic kits, reagents, drugs, face masks, and PPE kits [161-164]. The 3D bioprinting-based additive manufacturing appears to be an attractive solution and holds promise to combat the shortage of these supplies. Using 3D printing, the fabrication of complex structures can be done and the printing can be adjustable for the production of the respiratory mask, face shields, ventilator valves, testing kits, and other equipment that are desirable during this pandemic [162]. However, standard safety and quality measures of medical devices should be regulated and taken care of in 3D printing labs to ensure the goodness of fit of the bioprinted materials for human use [159] which can be improved through education, monitoring, and quality testing of procedures.

In the current pandemic, 3D printers have been used for rapid design and development of the equipment and testing kits which include a nasopharyngeal swab, personal protective equipment, and face shields. Moreover, an alternative approach for drug production and validation was done by multi-compartment and multi-layer 3D printing which was used for developing variable or fixed-dose combinations of two or more anti-viral therapeutics [164, 165]. The costeffective nasal swabs were designed and printed using polyethylene terephthalate glycol (PETG) filament by major type of filament-based printer at the Department of Pathology and Microbiology, University of Nebraska Medical Centre, Omaha, NE, USA. These swabs are durable, chemically inert, and well suited for structural applications [165]. Similarly, an inkjet-powder bed printer was used for drug loading as it dissolves drugs quickly and easily therefore can lower the drug administration burden for critically ill patients. This enhancement of drug solubility using FDM filaments which are created with ASD formulations is done by locking the active drug compounds into a formulated filament. This reduces the potential misuse of drug treatment during the panic of an ongoing crisis [164, 166]. Furthermore, 3D printing has already been used to produce respirator valves for the ventilators in Italy [167]. The 3D printable medical resources substantially reduce the morbidity and mortality in patients during the COVID-19 challenge. However, the cost of 3D printers and synthetic bioinks, and the low viability of cells with a lack of vascular networks are certain drawbacks of 3D printing techniques that need to be resolved. Another limitation of this technique is the use of a synthetic scaffold that does not mimic the cells' environment; however, this can be overcome by using the naturally derived extracellular matrix (ECM) through the process of decellularization.

Future Perspective

The $3 \mathrm{D}$ bioprinting technique is a boon to patients having end-stage organ failure. These techniques can also be used for regenerating amputee organs and help the person to live a normal lifestyle who lost the organ or limbs accidentally. Apart from this, it can be successfully implemented in the field of personalized regenerative medicine and tissue engineering. The advances in the designing of bioengineered scaffold/ extracellular matrix such as biocompatible biomaterial with minimum toxicity in the patients, angiogenesis promoting growth factors, biosensors in bioengineered scaffold which provide a timely update before perfusion of scaffold or extracellular matrix the cells and the ability of genetic manipulation of cells to prevent the disease have made these techniques most attractive and feasible to use. However, 3D tissue construct with precisely defined structures and geometries can be achieved using 3D printing techniques but these structures are not much stimulus-responsive which limits its application. Recently, 4D bioprinting and xenotransplantation have gained considerable attention in this regard. 4D bioprinting was first introduced in 2013 and since then it is rapidly growing. 4D printing technology offers a great ability to fabricate complex and stimuli-responsive 4D structures. In this technology, the 3D structure of an organ self-transforms immediately after printing when it is exposed to ultraviolet light, current, heat, or other energy sources or the predetermined stimulus, including osmotic pressure and exposure [168]. Skylar Tibbets in 2014 at the Massachusetts Institute of Technology (MIT) demonstrated multi-material printing that can change from one shape to another using 4D printing technology [169]. The homogenized tissue developed by 3D printing technology can be transformed into a fourth dimension using 4D bioprinting [170]. The five important factors taken in to account in the process of $4 \mathrm{D}$ printing are (1) mathematical modeling of the material transformation, (2) type of stimulus, (3) type of responsive material, (4) type of additive manufacturing process, and (5) interaction mechanism between stimulus and the material [171].

For successful 4D printing of tissue, numerical and theoretical models are mainly used. These models predict the time required for the structure to reflect the response by making links between material and stimulus properties, sequence of stimuli structure, and the desired final shape [172]. 4D printing technology involves multi-material printing that is stimuliresponsive materials, the shape of the material changes over time due to the reaction to temperature, $\mathrm{pH}$, humidity, electricity, magnetic field, light, acoustics, or a combination of 
these stimuli $[173,174]$. 4D bioprinting has diverse application in various fields which includes biomedical, tissue engineering, biosensors, robotics, and bioactuators. The fabrication of smart and multifunctional materials of biological relevance using 4D printing technology has been reported in recent studies $[175,176]$. The in vitro synthesis of biomimetic blood vessels using self-folding polymers which help blood vessels to incorporate into various cell types are successfully constructed using 4D printing [177]. Besides this, 4D bioprinting enables the allocation of distinct elements that can self-fold or self-unfold to encapsulate and release drugs or cells in a programmable manner to the target organ [178]. Another interesting application of 4D bioprinting technology is to cure wounds. For this, human adipose-derived stem cells are infused into shape memory polymer scaffolds, in which cells upon injury in scaffolds produced mineral deposition, protein production, and gene expression thereby healing the damaged tissue. The feasibility of printed shape memory scaffolds for bone repair has been proven experimentally [179].

Another advance in the field of tissue engineering is xenotransplantation [180-184]. A recent study done by VunjakNovakovic and her colleagues is the classic example of xenotransplantation. They had revived the donor lung (human) using pig (circulatory system) as a recipient. They obtained lungs that had been rejected for transplantation from six human donors, both single lungs and pairs. The team united each lung to the circulatory system of an anesthetized pig with tubes nourishing the blood vessels of the human lung from those in the neck of the pig. The circulatory system was inserted with immunosuppressant drugs which infiltrate both the pig and the human lung. After $24 \mathrm{~h}$, the team observes the lungs are modified. This study also stated that the process will not protect potentially harmful pathogens diffused to people. Furthermore, it was observed that the lungs are wholly free of pig cells. However, the lungs were noticed to have lymphocytes from the pigs. The outcome of this study provides a hope that lung recipient uses their blood supply to revive donated lungs that they will receive which could increase the number of lungs available for donation to patients by three times [184].

Currently, clinical xenotransplantation trials are in progress to detect the inherently engineered finest pig either as a single organ donor or multiple organ donor. However, it is uncertain whether a specific genetically engineered pig would be ideal as a source of numerous different complex organs or it would be necessary to have organ-specific genetically engineered pigs since organ-specific heterogeneity and immunogenicity play important role in the acceptance of transplanted organ [182]. In this regard, 3D bioprinting in combination with bioinformatics and computational biology can be proven less expensive and a quick way to get desired tissue or organ. However, there are several persisting pathobiological and physiological obstacles that must be conquered before worldwide acceptance of this technology [183].

\section{Commercially Available 3D Bioprinters}

Technological advancements are projected rapidly owing to the growing use of 3D bioprinting not only in the field of mass production of organs and tissues to overcome the organ shortage but this is also exploited in cosmetic surgeries and praises a lot in pharmaceutical industries. Currently, the 3D bioprinting global market is in its developing phase and has a huge opportunity to spread in developing countries. So far, only a handful of companies enlisted in Table 4 are in the market. 3D bioprinting technologies are still in their early stages in the field of biomedical research and development.

\section{Conclusion}

This review focused on additive manufacturing techniques specifically $3 \mathrm{D}$ bioprinting and decellularization followed by recellularization which hold promise to combat shortage of organs and can efficiently deal with several problems in the medical field. These techniques can be exploited for generation of customized organs for the patients facing end-stage organ failure. These approaches can be successfully implemented for personalized and regenerative medicine and thus can be boon for society and human welfare. The $3 \mathrm{D}$ bioprinting working principle is similar to 2D printers in which instead of using paper and colored ink, specific material such as hydrogels, biomaterials, stem cells, or patient-derived cells have been used along with file in the STL format to create a tissue or organ. The most common bioprinters in the field of tissue engineering and 3D printing technology are laser-assisted printer, microextrusion, and inkjet printers which basically use different biomaterial and bioink. These biomaterials are compatible with printers and specialized to properly fabricate the tissue/organ construct. In contrast to this, decellularization is used to customize or personalize the donor organ for the patient via removing all the cellular components and the genetic material to get the naturally derived extracellular matrix called scaffold. The more personalized and natural extracellular matrix can be obtained using 3D bioprinting and decellularization approaches that can be adapted to body without eliciting much immune response in contrast to synthetic matrix where chances of rejection are higher. However, stability and natural shape of organ along with cost of techniques are few factors which limit the applicability of these techniques. Besides, the ethical approval of governing bodies of countries in terms of human organ culture and usages would be another major challenge in this regard. Nevertheless, recent advances in 4D bioprinting have ability to enhance the structural stability and shape of the tissue/organ construct. Moreover, xenotransplantation has potential to revive the donor organ without transmitting the xenogeneic disease in human recipient. Taken together, these techniques if exploited precisely and appropriately can deal with the problem of shortage of organs in the field of medical sciences. 


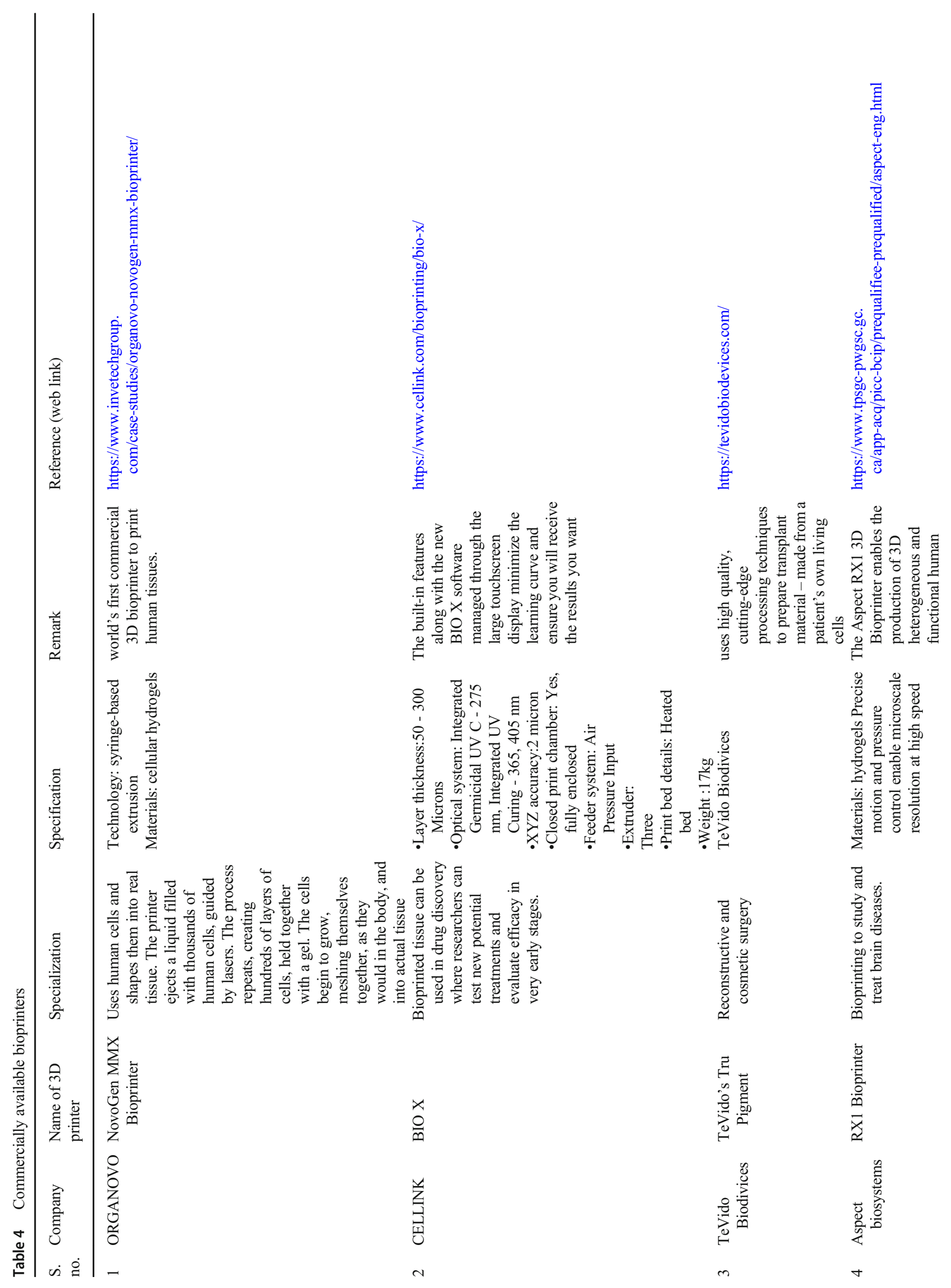




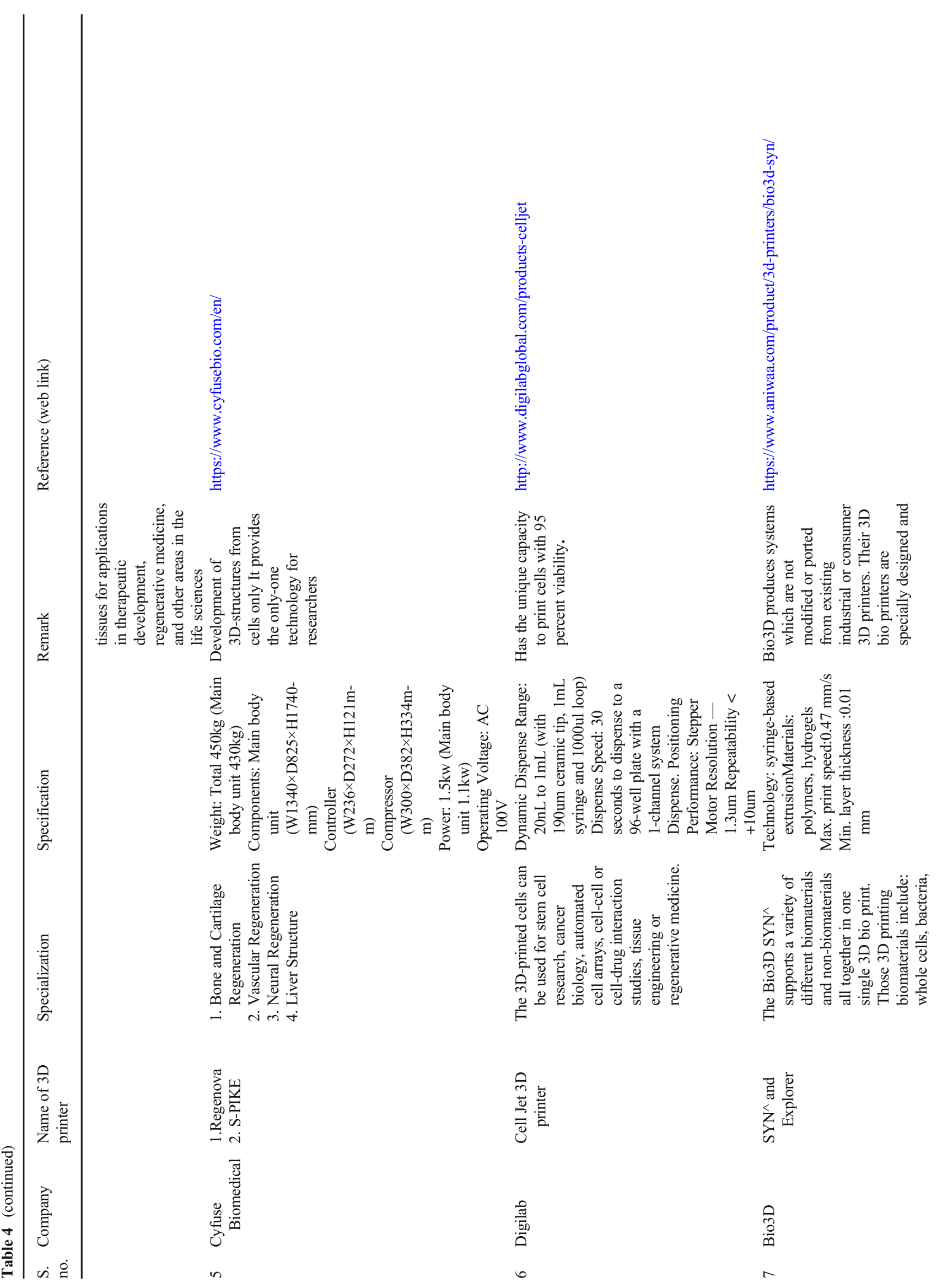




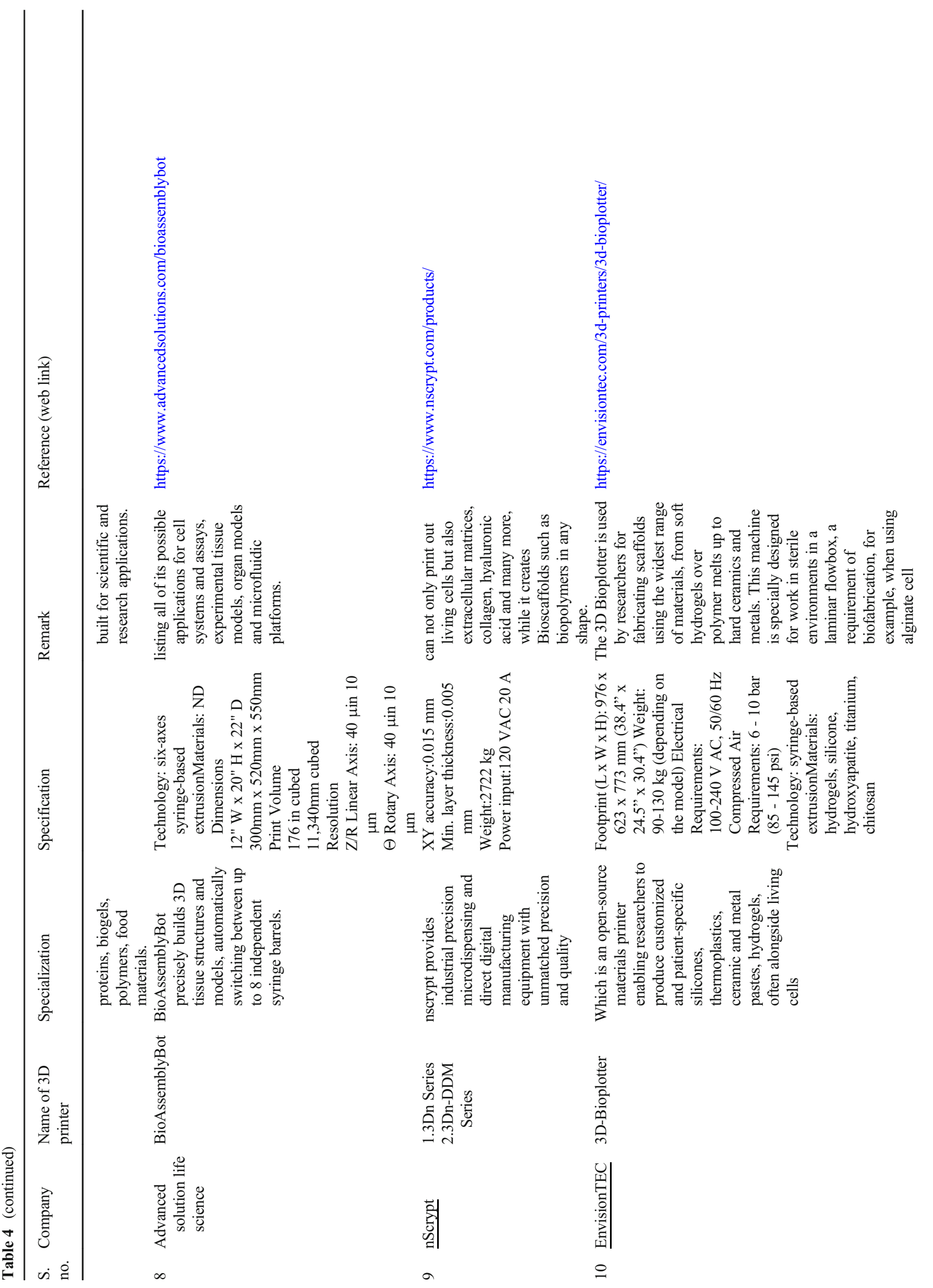




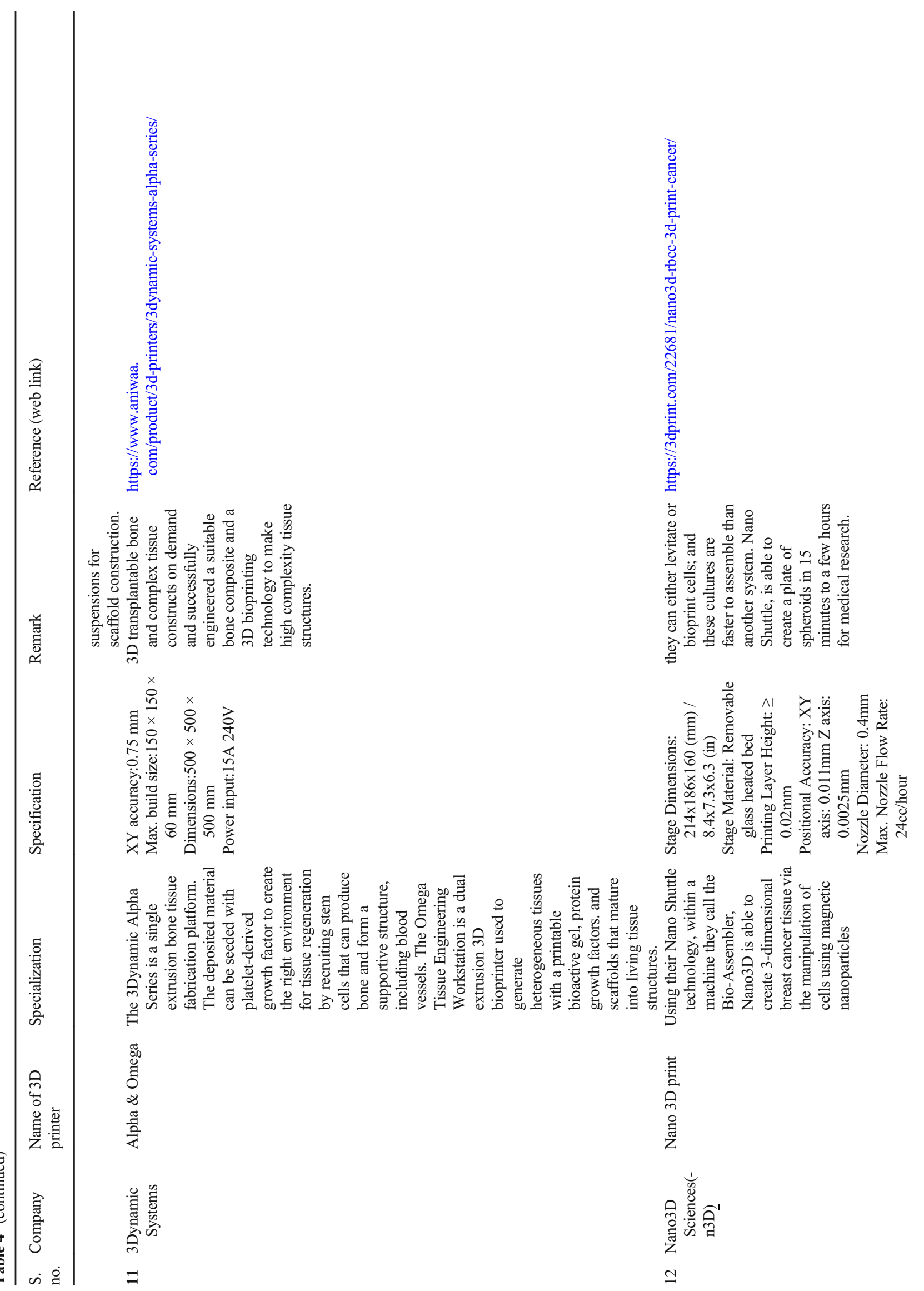




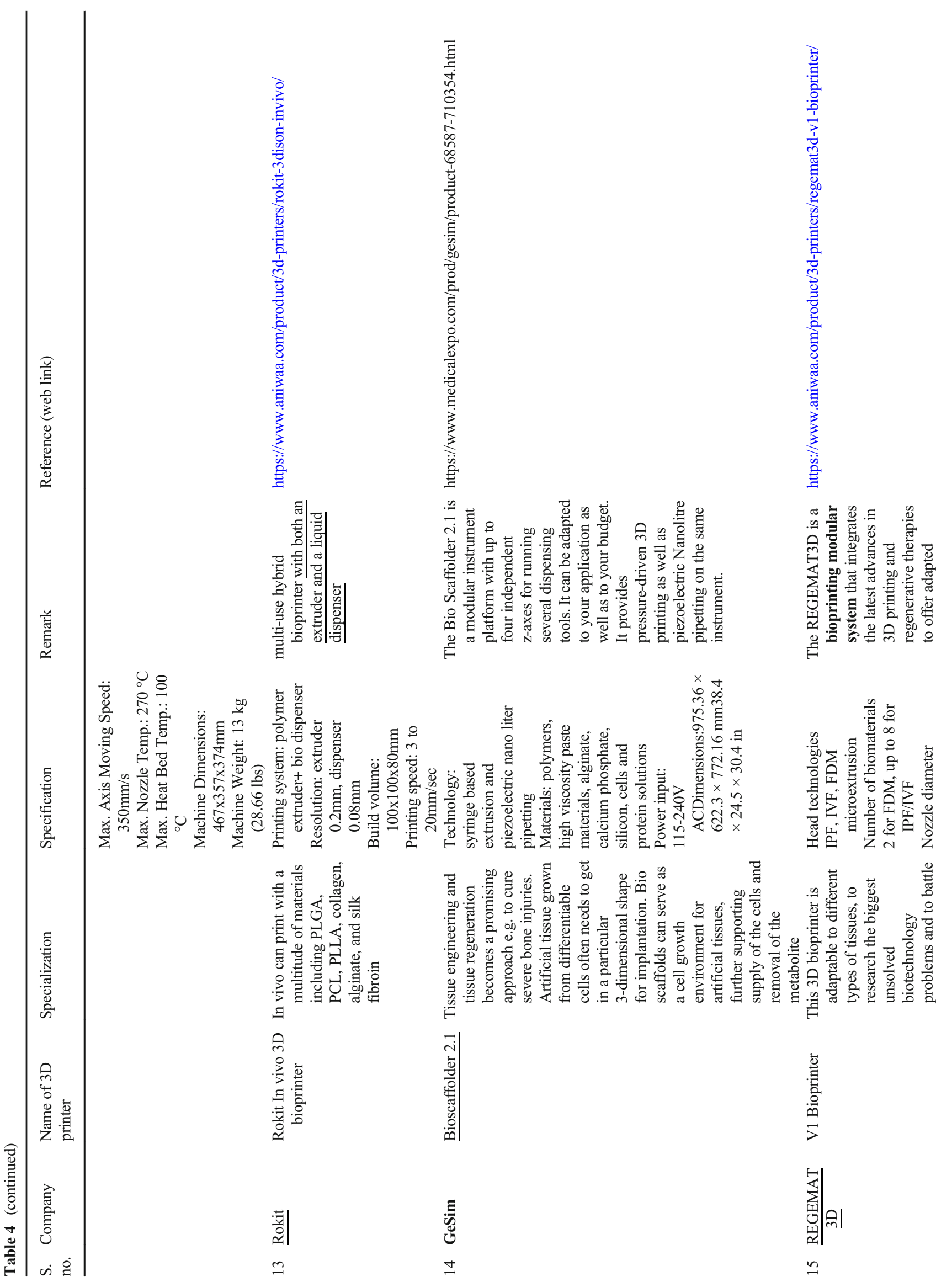




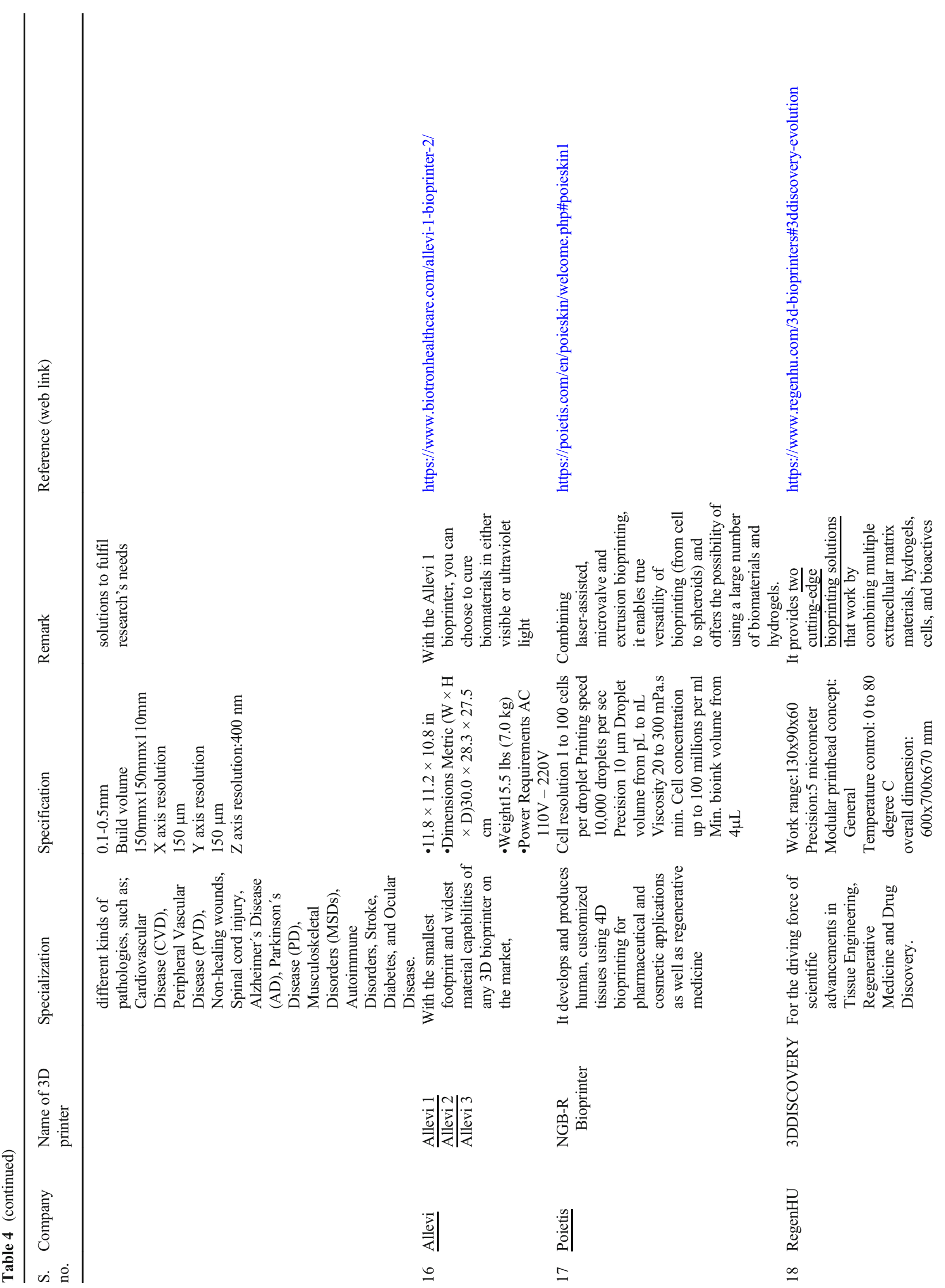




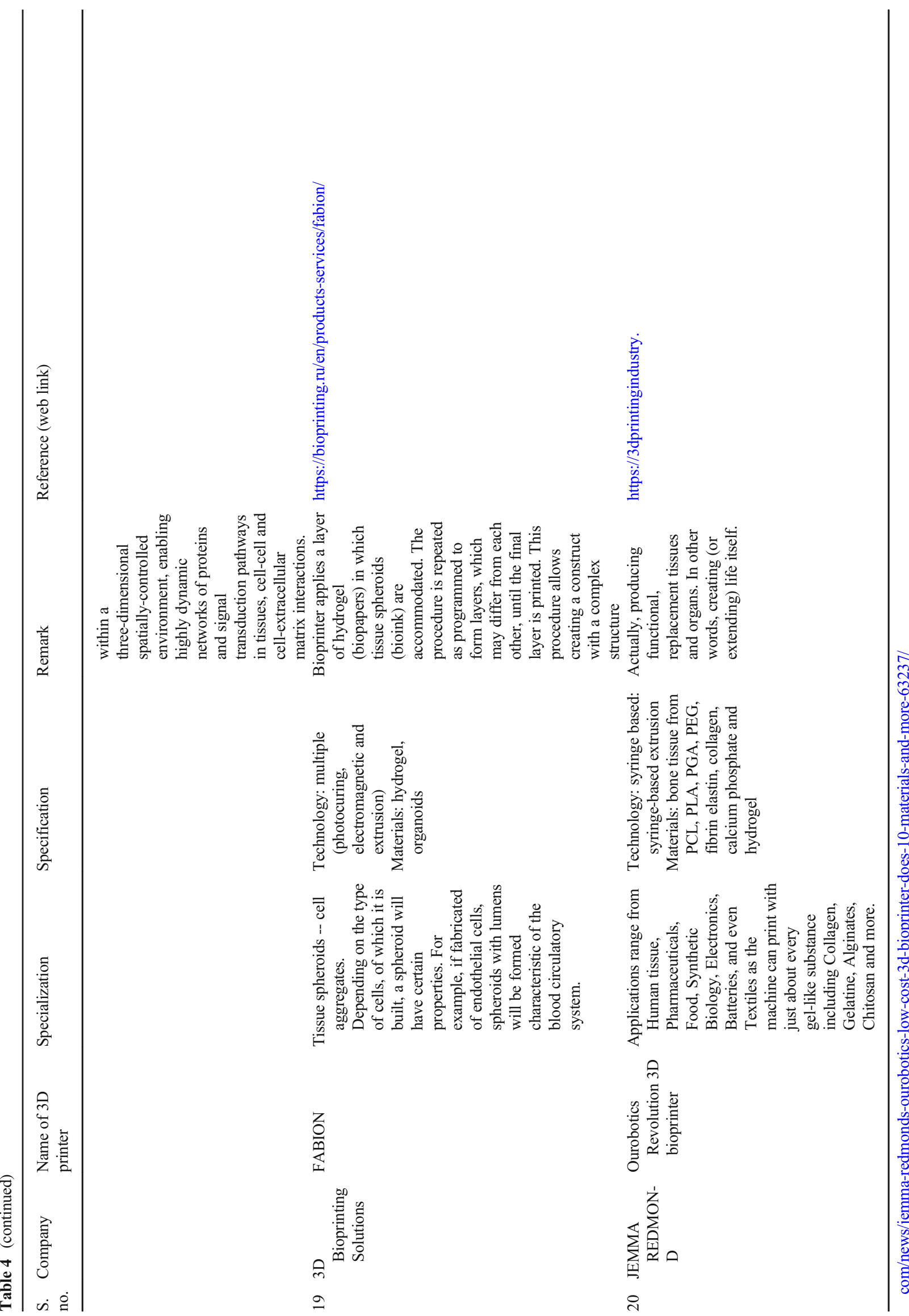


Author Contribution AP-conceived the idea, wrote the manuscript, edited the final draft. VP, DSP, NP-collected the data, draw figures and tables, wrote the first draft. RK, AK, TB-provided constructive suggestion, and wrote and edited the final draft of manuscript.

\section{Data Availability NA}

\section{Declarations}

Ethical Approval No ethical approval needed for this article

\section{Consent to Participate NA}

Consent to Publish NA

Conflict of Interest The authors declare no competing interests.

\section{References}

1. Organ Procurement and Transplantation Network. U.S. Department of Health \& Human Services https://optn.transplant. hrsa.gov/ (Date accessed 22/04/2021)

2. Organ Donation and Transplantation Statistics. National Kidney Foundation. https://www.kidney.org/news/newsroom/factsheets/ Organ-Donation-and-Transplantation-Stats (Date accessed 22/ 04/2021)

3. Indian Transplant Registry. Indian society of organ transplantation. http://www.transplantindia.com/ (Date accessed 22/04/2021)

4. Calne RY. Organ transplantation has come of age. Sci Prog. 2010;93:141-50.

5. Abouna GM. Organ shortage crisis: problems and possible solutions. Transplant Proc. 2008;40:34-8 Available from: https:// linkinghub.elsevier.com/retrieve/pii/S0041134507014595176. Accessed 20/04/2021.

6. Saidi RF, Hejazii Kenari SK. Challenges of organ shortage for transplantation: solutions and opportunities. Int J Organ Transplant Med. 2014;5:87-96 Available from: http://www.ncbi. nlm.nih.gov/pubmed/25184029175. Accessed 20/04/2021.

7. Wall SP, Plunkett C, Caplan A. A potential solution to the shortage of solid organs for transplantation. JAMA. 2015;313:2321 Available from: http://jama.jamanetwork.com/article.aspx?doi= 10.1001/jama.2015.5328174. Accessed 20/04/2021.

8. Srivastava A, Mani A. Deceased organ donation and transplantation in India: promises and challenges. Neurol India. 2018;66:316. Available from: http://www.neurologyindia.com/text.asp?2018/ 66/2/316/227259173-22. Accessed 29/07/2020.

9. Shroff S. Legal and ethical aspects of organ donation and transplantation. Indian J Urol. 2009;25:348 Available from: http:// www.indianjurol.com/text.asp?2009/25/3/348/56203172.

10. Gao G, Cui X. Three-dimensional bioprinting in tissue engineering and regenerative medicine. Biotechnol Lett. 2016;38:203-11 171

11. Guan X, Avci-Adali M, Alarçin E, Cheng H, Kashaf SS, Li Y, et al. Development of hydrogels for regenerative engineering. Biotechnol J. 2017;12:170.

12. Shahrubudin N, Lee TC, Ramlan R. An overview on 3D printing technology: technological, materials, and applications. Procedia Manuf. 2019;35:1286-96 Available from:https://linkinghub. elsevier.com/retrieve/pii/S2351978919308169169.

13. Rajan V, Sniderman B, Baum P. 3D opportunity for life: additive manufacturing takes humanitarian action. Delight Insight. 2016;1(19):1-8.
14. Petroşanu AP, D-M. The impact of $3 \mathrm{~d}$ printing technology on the society and economy. Rom Econ Bus Rev. 2013;7(2):360-70.

15. Porzionato A, Stocco E, Barbon S, Grandi F, Macchi V, De Caro R. Tissue-engineered grafts from human decellularized extracellular matrices: a systematic review and future perspectives. Int $\mathbf{J}$ Mol Sci. 2018;19:4117 Available from: http://www.mdpi.com/ 1422-0067/19/12/4117166.

16. Abaci A, Guvendiren M. Designing decellularized extracellular matrix-based bioinks for 3D bioprinting. Adv Healthc Mater. 2020;9:2000734 Available from:https://onlinelibrary.wiley.com/ doi/10.1002/adhm.202000734165.

17. Kabirian F, Mozafari M. Decellularized ECM-derived bioinks: prospects for the future. Methods. 2020;171:108-18 Available from: https://linkinghub.elsevier.com/retrieve/pii/ S1046202318304377164.

18. Dzobo K, Motaung KSCM, Adesida A. Recent trends in decellularized extracellular matrix bioinks for 3D printing: an updated review. Int J Mol Sci [ spacebar]. 2019;20:4628 Available from: https://www.mdpi.com/1422-0067/20/18/4628163.

19. Dzobo K, Thomford NE, Senthebane DA, Shipanga H, Rowe A, Dandara $\mathrm{C}$, et al. Advances in regenerative medicine and tissue engineering: innovation and transformation of medicine. Stem Cells Int. 2018;2018:1-24 Available from:https://www.hindawi. com/journals/sci/2018/2495848/162.

20. Mao AS, Mooney DJ. Regenerative medicine: current therapies and future directions. Proc Natl Acad Sci. 2015;112:14452-9 Available from:http://www.pnas.org/lookup/doi/10.1073/pnas. 1508520112161.

21. Khan AA, Vishwakarma SK, Bardia A, Venkateshwarulu J. Repopulation of decellularized whole organ scaffold using stem cells: an emerging technology for the development of neo-organ. J Artif Organs. 2014;17:291-300 Available from: http://link. springer.com/10.1007/s10047-014-0780-2160.

22. Iravani S, Varma RS. Plants and plant-based polymers as scaffolds for tissue engineering. Green Chem. 2019;21:4839-67 159.

23. Dhandayuthapani B, Yoshida Y, Maekawa T, Kumar DS. Polymeric scaffolds in tissue engineering application: a review. Int J Polym Sci [spacebar]. 2011;2011:1-19 Available from: http://www.hindawi.com/journals/ijps/2011/290602/158.

24. Chan BP, Leong KW. Scaffolding in tissue engineering: general approaches and tissue-specific considerations. Eur Spine J [ spacebar]. 2008;17:467-79 Available from: http://link.springer. com/10.1007/s00586-008-0745-3157.

25. Amado S, Morouço P, Pascoal-Faria P, Alves N. Tailoring bioengineered scaffolds for regenerative medicine. Biomater Regen Med [ spacebar]. InTech; 2018. Available from: http:// www.intechopen.com/books/biomaterials-in-regenerativemedicine/tailoring-bioengineered-scaffolds-for-regenerativemedicine 156.

26. Pina S, Ribeiro VP, Marques CF, Maia FR, Silva TH, Reis RL, et al. Scaffolding strategies for tissue engineering and regenerative medicine applications. Mater (Basel) [ spacebar]. 2019;12:1824 Available from: https://www.mdpi.com/1996-1944/12/11/ 1824155.

27. Chae T, Yang H, Leung V, Ko F, Troczynski T. Novel biomimetic hydroxyapatite/alginate nanocomposite fibrous scaffolds for bone tissue regeneration. J Mater Sci Mater Med. 2013;24:1885-94 Available from: http://link.springer.com/10.1007/s10856-0134957-7154.

28. Tapias LF, Ott HC. Decellularized scaffolds as a platform for bioengineered organs. Curr Opin Organ Transplant. 2014;19: 145-52 Available from: http://journals.lww.com/00075200201404000-00012153.

29. Eltom A, Zhong G, Muhammad A. Scaffold techniques and designs in tissue engineering functions and purposes: a review. Adv Mater Sci Eng. 2019;2019:152. 
30. Guyette JP, Gilpin SE, Charest JM, Tapias LF, Ren X, Ott HC. Perfusion decellularization of whole organs. Nat Protoc. 2014;9: 1451-68 Available from: http://www.nature.com/articles/nprot. 2014.097151.

31. Gilpin A, Yang Y. Decellularization strategies for regenerative medicine: from processing techniques to applications. Biomed Res Int. 2017;2017:1-13 Available from: https:/www.hindawi. com/journals/bmri/2017/9831534/150.

32. Crapo PM, Gilbert TW, Badylak SF. An overview of tissue and whole organ decellularization processes. Biomaterials. 2011;32: 3233-43 Available from: https://linkinghub.elsevier.com/ retrieve/pii/S0142961211000895149.

33. Badylak SF, Taylor D, Uygun K. Whole-organ tissue engineering: decellularization and recellularization of three-dimensional matrix scaffolds. Annu Rev Biomed Eng. 2011;13:27-53 Available from: http://www.annualreviews.org/doi/10.1146/annurevbioeng-071910-124743148.

34. Rana D, Zreiqat H, Benkirane-Jessel N, Ramakrishna S, Ramalingam M. Development of decellularized scaffolds for stem cell-driven tissue engineering. J Tissue Eng Regen Med. 2017;11: 942-65 Available from: http://doi.wiley.com/10.1002/term. 2061147.

35. Hrebikova H, Diaz D, Mokry J. Chemical decellularization: a promising approach for preparation of extracellular matrix. Biomed Pap. 2015;159:012-7 Available from: http://biomed. papers.upol.cz/doi/10.5507/bp.2013.076.html146.

36. Shirakigawa N, Ijima H. Decellularized tissue engineering. 2017. p. 185-226. Available from: http://link.springer.com/10.1007/ 978-981-10-3328-5 5145 .

37. Porzionato A, Stocco E, Barbon S, Grandi F, Macchi V, De Caro R. Tissue-engineered grafts from human decellularized extracellular matrices: a systematic review and future perspectives. Int J Mol Sci. 2018;19:4117 Available from: http://www.mdpi.com/ 1422-0067/19/12/4117144.

38. Zambaiti E, Scottoni F, Rizzi E, Russo S, Deguchi K, Eaton S, et al. Whole rat stomach decellularisation using a detergentenzymatic protocol. Pediatr Surg Int. 2019;35:21-7 Available from: http://link.springer.com/10.1007/s00383-018-4372-8143.

39. Gilbert T, Sellaro T, Badylak S. Decellularization of tissues and organs. Biomaterials. 2006; Available from: https://linkinghub. elsevier.com/retrieve/pii/S0142961206001682142.

40. Nonaka PN, Campillo N, Uriarte JJ, Garreta E, Melo E, de Oliveira LVF, et al. Effects of freezing/thawing on the mechanical properties of decellularized lungs. J Biomed Mater Res Part A. 2014;102:413-9 Available from: http://doi.wiley.com/10.1002/ jbm.a.34708141.

41. Merna N, Robertson C, La A, George SC. Optical imaging predicts mechanical properties during decellularization of cardiac tissue. Tissue Eng Part C Methods. 2013;19:802-9 Available from: https://www.liebertpub.com/doi/10.1089/ten.tec.2012.0720140.

42. Keane TJ, Londono R, Turner NJ, Badylak SF. Consequences of ineffective decellularization of biologic scaffolds on the host response. Biomaterials. 2012;33:1771-81 139.

43. Cheng CW, Solorio LD, Alsberg E. Decellularized tissue and cellderived extracellular matrices as scaffolds for orthopaedic tissue engineering. Biotechnol Adv. 2014;32:462-84 Available from: https://linkinghub.elsevier.com/retrieve/pii/ S0734975014000044138.

44. Rahmati M, Pennisi CP, Mobasheri A, Mozafari M. Bioengineered scaffolds for stem cell applications in tissue engineering and regenerative medicine. Adv Exp Med Biol. 2018;1107:73-89 137.

45. Uzarski JS, Su J, Xie Y, Zhang ZJ, Ward HH, Wandinger-Ness A, et al. Epithelial cell repopulation and preparation of rodent extracellular matrix scaffolds for renal tissue development. J Vis Exp . 2015; Available from: http://www.jove.com/video/53271/ epithelial-cell-repopulation-preparation-rodent-extracellularmatrix 136.

46. Ott HC, Matthiesen TS, Goh S-K, Black LD, Kren SM, Netoff TI, et al. Perfusion-decellularized matrix: using nature's platform to engineer a bioartificial heart. Nat Med. 2008;14:213-21 Available from:http://www.nature.com/articles/nm1684130.

47. Weymann A, Patil NP, Sabashnikov A, Jungebluth P, Korkmaz S, Li S, et al. Bioartificial heart: a human-sized porcine model - the way ahead. Benedetto U, editor. PLoS One. 2014;9:e111591 Available from: https://dx.plos.org/10.1371/journal.pone. 0111591135.

48. Fishman JM, Lowdell M, Birchall MA. Stem cell-based organ replacements - airway and lung tissue engineering. Semin Pediatr Surg. 2014;23:119-26 Available from: https:// linkinghub.elsevier.com/retrieve/pii/S1055858614000122134.

49. Wang B, Tedder ME, Perez CE, Wang G, de Jongh Curry AL, To F, et al. Structural and biomechanical characterizations of porcine myocardial extracellular matrix. J Mater Sci Mater Med. 2012;23: 1835-47 Available from: http://link.springer.com/10.1007/ s10856-012-4660-0133.

50. Lichtenberg A. Preclinical testing of tissue-engineered heart valves re-endothelialized under simulated physiological conditions. Circulation. 2006;114:I-559 - 565 Available from: http:// circ.ahajournals.org/cgi/doi/10.1161/CIRCULATIONAHA.105. 001206132.

51. Kasimir M-T, Weigel G, Sharma J, Rieder E, Seebacher G, Wolner E, et al. The decellularized porcine heart valve matrix in tissue engineering. Thromb Haemost. 2005;94:562-7 Available from: http://www.thieme-connect.de/DOI/DOI?10.1160/TH0501-0025131.

52. Uygun BE, Soto-Gutierrez A, Yagi H, Izamis M-L, Guzzardi MA, Shulman C, et al. Organ reengineering through development of a transplantable recellularized liver graft using decellularized liver matrix. Nat Med. 2010;16:814-20 Available from: http://www. nature.com/articles/nm.2170129.

53. Petersen TH, Calle EA, Zhao L, Lee EJ, Gui L, Raredon MB, et al. Tissue-engineered lungs for in vivo implantation. Science (80-). 2010;329:538-41 Available from: https://www.sciencemag.org/ lookup/doi/10.1126/science.1189345128.

54. Price AP, England KA, Matson AM, Blazar BR, PanoskaltsisMortari A. Development of a decellularized lung bioreactor system for bioengineering the lung: the matrix reloaded. Tissue Eng Part A. 2010;16:2581-91 Available from: https://www.liebertpub. com/doi/10.1089/ten.tea.2009.0659127.

55. Ross CL, Booth C, Sanders B, Babbar P, Bergman C, Soker T, et al. Regeneration and bioengineering of transplantable abdominal organs: current status and future challenges. Expert Opin Biol Ther. 2013;13:103-13 Available from: http://www.tandfonline. com/doi/full/10.1517/14712598.2013.732063126.

56. Cui H, Nowicki M, Fisher JP, Zhang LG. 3D Bioprinting for organ regeneration. Adv Healthc Mater. 2017;6:1601118 Available from: http://doi.wiley.com/10.1002/adhm. 201601118125. Accessed 24/09/2020.

57. Ozbolat IT. Bioprinting scale-up tissue and organ constructs for transplantation. Trends Biotechnol. 2015;33:395-400 Available from: https://linkinghub.elsevier.com/retrieve/pii/ S0167779915000967124.

58. Wang X, Ao Q, Tian X, Fan J, Wei Y, Hou W, et al. 3D bioprinting technologies for hard tissue and organ engineering. Materials (Basel). 2016;9:802 Available from: http://www.mdpi. com/1996-1944/9/10/802123. Accessed 24/09/2020.

59. Wang X. Bioartificial Organ Manufacturing Technologies. Cell Transplant. 2019;28:5-17 Available from: http://journals. sagepub.com/doi/10.1177/0963689718809918122. 
60. Pati F, Gantelius J, Svahn HA. 3D bioprinting of tissue/organ models. Angew Chem Int Ed. 2016;55:4650-65 Available from: http://doi.wiley.com/10.1002/anie.201505062121.

61. Melchels FPW, Domingos MAN, Klein TJ, Malda J, Bartolo PJ, Hutmacher DW. Additive manufacturing of tissues and organs. Prog Polym Sci. 2012;37:1079-104 Available from: https:// linkinghub.elsevier.com/retrieve/pii/S0079670011001328120.

62. Mironov V, Prestwich G, Forgacs G. Bioprinting living structures. J Mater Chem. 2007;17:2054 Available from: http://xlink.rsc. org/?DOI=b617903g119. Accessed 18/12/2020.

63. Mironov V, Reis N, Derby B. Review: Bioprinting: a beginning. Tissue Eng. 2006;12:631-4 Available from: https://www. liebertpub.com/doi/10.1089/ten.2006.12.631118.

64. Mironov V, Kasyanov V, Markwald RR. Organ printing: from bioprinter to organ biofabrication line. Curr Opin Biotechnol. 2011;22:667-73 Available from: https://linkinghub.elsevier.com/ retrieve/pii/S0958166911000334117.

65. Passamai VE, Dernowsek JA, Nogueira J, Lara V, Vilalba F, Mironov VA, et al. From 3D bioprinters to a fully integrated organ biofabrication line. J Phys Conf Ser. 2016;705:012010 Available from: https://iopscience.iop.org/article/10.1088/1742-6596/705/1/ 012010116

66. Mandrycky CZ, Kim K, Kim D-H. 3D bioprinting for engineering complex tissues. Biotechnol Adv. 2016;34:422-34 Available from: https://linkinghub.elsevier.com/retrieve/pii/ S0734975015300665115.

67. Yi H-G, Lee H, Cho D-W. 3D printing of organs-on-chips. Bioengineering. 2017;4:10 Available from: http://www.mdpi. com/2306-5354/4/1/10114. Accessed 24/09/2020.

68. Munaz A, Vadivelu RK, St. John J, Barton M, Kamble H, Nguyen N-T. Three-dimensional printing of biological matters. J Sci Adv Mater Devices. 2016;1:1-17 Available from: https://inkinghub. elsevier.com/retrieve/pii/S2468217916300144113.

69. Ozbolat IT, Yin Y. Bioprinting toward organ fabrication: challenges and future trends. IEEE Trans Biomed Eng. 2013;60: 691-9 Available from: http://ieeexplore.ieee.org/document/ 6423824/112.

70. Stachowiak JC, Richmond DL, Li TH, Brochard-Wyart F, Fletcher DA. Inkjet formation of unilamellar lipid vesicles for cell-like encapsulation. Lab Chip. 2009;9:2003 Available from: http://xlink.rsc.org/?DOI=b904984c111.

71. Le HP, Le Technologies, Inc. Beaverton O. Progress and trends in ink-jet printing technology. J Imaging Sci Technol. 1998;42:110.

72. Dababneh AB, Ozbolat IT. Bioprinting technology: a current state-of-the-art review. J Manuf Sci Eng. 2014;136 Available from: https://asmedigitalcollection.asme.org/ manufacturingscience/article/doi/10.1115/1.4028512/377608/ Bioprinting-Technology-A-Current-StateoftheArt109.

73. Koch L, Kuhn S, Sorg H, Gruene M, Schlie S, Gaebel R, et al. Laser printing of skin cells and human stem cells. Tissue Eng Part C Methods. 2010;16:847-54 Available from: https://www. liebertpub.com/doi/10.1089/ten.tec.2009.0397108.

74. Park JH, Jang J, Lee JS, Cho DW. Three-dimensional printing of tissue/organ analogues containing living cells. Ann Biomed Eng. 2017:45:180-94 107.

75. Cui H, Nowicki M, Fisher JP, Zhang LG. 3D Bioprinting for organ regeneration. Adv Healthc Mater. 2017;6:1601118 Available from: http://doi.wiley.com/10.1002/adhm. 201601118106

76. Donderwinkel I, van Hest JCM, Cameron NR. Bio-inks for 3D bioprinting: recent advances and future prospects. Polym Chem. 2017;8:4451-71 Available from: http://xlink.rsc.org/?DOI= C7PY00826K105.

77. Zhu W, Wang M, Fu Y, Castro NJ, Fu SW, Zhang LG. Engineering a biomimetic three-dimensional nanostructured bone model for breast cancer bone metastasis study. Acta Biomater.
2015;14:164-74 Available from: https://linkinghub.elsevier. com/retrieve/pii/S1742706114005728104.

78. Miao S, Zhu W, Castro NJ, Nowicki M, Zhou X, Cui H, et al. 4D printing smart biomedical scaffolds with novel soybean oil epoxidized acrylate. Sci Rep. 2016;6:27226 Available from: http:// www.nature.com/articles/srep27226103.

79. Hull C. On stereolithography. Virtual and Physical Prototyping. 2012;7(3):177. https://doi.org/10.1080/17452759.2012.723409.

80. Lipson H, Moon FC, Hai J, Paventi C. 3-D printing the history of mechanisms. Mech Des. 2004; 101. Hull C. On Stereolithography. Virtual Phys Prototyp. 2012;7:177 Available from: http://www. tandfonline.com/doi/abs/10.1080/17452759.2012.723409102.

81. Rodríguez-Dévora JI, Zhang B, Reyna D, Shi Z, Xu T. High throughput miniature drug-screening platform using bioprinting technology. Biofabrication. 2012;4:035001 Available from: https://iopscience.iop.org/article/10.1088/1758-5082/4/3/ 035001100 .

82. Horváth L, Umehara Y, Jud C, Blank F, Petri-Fink A, RothenRutishauser B. Engineering an in vitro air-blood barrier by 3D bioprinting. Sci Rep. 2015;5:7974 Available from: http://www. nature.com/articles/srep0797499.

83. Mironov V, Trusk T, Kasyanov V, Little S, Swaja R, Markwald R. Biofabrication: a 21 st century manufacturing paradigm. Biofabrication. 2009;1:022001 Available from: http://www.ncbi. nlm.nih.gov/pubmed/2081109998.

84. Ozbolat IT, Hospodiuk M. Current advances and future perspectives in extrusion-based bioprinting. Biomaterials. 2016;76:32143 Available from: https://linkinghub.elsevier.com/retrieve/pii/ S014296121500886897.

85. Gudapati H, Dey M, Ozbolat I. A comprehensive review on droplet-based bioprinting: past, present and future. Biomaterials. 2016;102:20-42 Available from: https://linkinghub.elsevier.com/ retrieve/pii/S014296121630266696.

86. Griffith LG, Swartz MA. Capturing complex 3D tissue physiology in vitro. Nat Rev Mol Cell Biol. 2006;7:211-24 Available from: http://www.nature.com/articles/nrm185895.

87. Lutolf MP, Hubbell JA. Synthetic biomaterials as instructive extracellular microenvironments for morphogenesis in tissue engineering. Nat Biotechnol. 2005;23:47-55 Available from: http:// www.nature.com/articles/nbt105594.

88. Gopinathan J, Noh I. Recent trends in bioinks for 3D printing. Biomater Res. 2018;22:11 Available from: https:// biomaterialsres.biomedcentral.com/articles/10.1186/s40824-0180122-193.

89. Hospodiuk M, Dey M, Sosnoski D, Ozbolat IT. The bioink: a comprehensive review on bioprintable materials. Biotechnol Adv. 2017;35:217-39 Available from: https://linkinghub. elsevier.com/retrieve/pii/S073497501630171992.

90. Ashammakhi N, Ahadian S, Xu C, Montazerian H, Ko H, Nasiri $\mathrm{R}$, et al. Bioinks and bioprinting technologies to make heterogeneous and biomimetic tissue constructs. Mater Today Bio. 2019;1: 100008 Available from: https://linkinghub.elsevier.com/retrieve/ pii/S259000641930014691.

91. Lei M, Wang X. Biodegradable polymers and stem cells for bioprinting. Molecules. 2016;21:539 Available from: http:// www.mdpi.com/1420-3049/21/5/53990.

92. Yang E, Miao S, Zhong J, Zhang Z, Mills DK, Zhang LG. Biobased polymers for 3D printing of bioscaffolds. Polym Rev. 2018;58:668-87 Available from: https://www.tandfonline.com/ doi/full/10.1080/15583724.2018.148476189.

93. Ligon SC, Liska R, Stampfl J, Gurr M, Mülhaupt R. Polymers for $3 \mathrm{D}$ printing and customized additive manufacturing. Chem Rev. 2017;117:10212-90 Available from: https://pubs.acs.org/doi/10. 1021/acs.chemrev.7b0007488.

94. Gul JZ, Sajid M, Rehman MM, Siddiqui GU, Shah I, Kim K-H, et al. 3D printing for soft robotics - a review. Sci Technol Adv 
Mater. 2018;19:243-62 Available from: https://www.tandfonline. com/doi/full/10.1080/14686996.2018.143186287.

95. Guvendiren M, Molde J, Soares RMD, Kohn J. Designing biomaterials for 3D printing. ACS Biomater Sci Eng. 2016;2:1679-93 Available from: https://pubs.acs.org/doi/10.1021/acsbiomaterials. 6b0012186.

96. Miller GE. Artificial Organs. Synth Lect Biomed Eng. 2006;1:172 Available from: http://www.morganclaypool.com/doi/abs/10. 2200/S00023ED1V01Y200604BME00485.

97. Buddy D. Ratner. et al. Biomaterial sciences: an introduction to materials in medicine. 1996. 84.

98. Murphy SV, Atala A. 3D bioprinting of tissues and organs. Nat Biotechnol. 2014;32:773-85 Available from: http://www.nature. com/articles/nbt.295883.

99. Lee V, Singh G, Trasatti JP, Bjornsson C, Xu X, Tran TN, et al. Design and fabrication of human skin by three-dimensional bioprinting. Tissue Eng Part C Methods. 2014;20:473-84 Available from: https://www.liebertpub.com/doi/10.1089/ten.tec. 2013.033578.

100. Tarassoli SP, Jessop ZM, Al-Sabah A, Gao N, Whitaker S, Doak $\mathrm{S}$, et al. Skin tissue engineering using 3D bioprinting: an evolving research field. J Plast Reconstr Aesthet Surg. 2018;71:615-23 Available from: https://linkinghub.elsevier.com/retrieve/pii/ S174868151730505376.

101. Admane P, Gupta AC, Jois P, Roy S, Chandrasekharan Lakshmanan C, Kalsi G, et al. Direct 3D bioprinted fullthickness skin constructs recapitulate regulatory signaling pathways and physiology of human skin. Bioprinting. 2019;15: e00051 Available from: https://linkinghub.elsevier.com/retrieve/ pii/S240588661830048475.

102. Biplab Das. Bioprinted human skin made. Nature India.2019. 74. https://www.natureasia.com/en/nindia/article/10.1038/nindia. 2019.70

103. Matsusaki M, Sakaue K, Kadowaki K, Akashi M. Threedimensional human tissue chips fabricated by rapid and automatic inkjet cell printing. Adv Healthc Mater. 2013;2:534-9 Available from: http://doi.wiley.com/10.1002/adhm.20120029973

104. Ma X, Qu X, Zhu W, Li Y-S, Yuan S, Zhang H, et al. Deterministically patterned biomimetic human iPSC-derived hepatic model via rapid 3D bioprinting. Proc Natl Acad Sci. 2016;113:2206-11 Available from: http://www.pnas.org/ lookup/doi/10.1073/pnas.152451011372.

105. Nguyen DG, Funk J, Robbins JB, Crogan-Grundy C, Presnell SC, Singer T, et al. Bioprinted 3D primary liver tissues allow assessment of organ-level response to clinical drug induced toxicity in vitro. van Grunsven LA, editor. PLoS One. 2016;11: e0158674. Available from: https://dx.plos.org/10.1371/journal. pone. 015867471

106. Lee H, Cho D-W. One-step fabrication of an organ-on-a-chip with spatial heterogeneity using a 3D bioprinting technology. Lab Chip. 2016;16:2618-25 Available from: http://xlink.rsc.org/? DOI=C6LC00450D69.

107. Bhise NS, Manoharan V, Massa S, Tamayol A, Ghaderi M, Miscuglio M, et al. A liver-on-a-chip platform with bioprinted hepatic spheroids. Biofabrication [ spacebar]. 2016;8:014101 Available from: https://iopscience.iop.org/article/10.1088/17585090/8/1/01410168

108. Tsimbouri PM, Childs PG, Pemberton GD, Yang J, Jayawarna V, Orapiriyakul W, et al. Stimulation of 3D osteogenesis by mesenchymal stem cells using a nanovibrational bioreactor. Nat Biomed Eng. 2017;1:758-70 Available from: http://www.nature.com/ articles/s41551-017-0127-4.

109. Catros S, Fricain J-C, Guillotin B, Pippenger B, Bareille R, Remy $\mathrm{M}$, et al. Laser-assisted bioprinting for creating on-demand patterns of human osteoprogenitor cells and nano-hydroxyapatite.
Biofabrication. 2011;3:025001 Available from: https:// iopscience.iop.org/article/10.1088/1758-5082/3/2/02500151.

110. Carolo L. 3D printed bones: the most jaw-dropping projects. 2020. All3DP https://all3dp.com/2/3d-printed-bones-projects/

111. Zhou Z, Lennon A, Buchanan F, McCarthy HO, Dunne N. Binder jetting additive manufacturing of hydroxyapatite powders: effects of adhesives on geometrical accuracy and green compressive strength. Addit Manuf. 2020;36:101645. https://doi.org/10.1016/ j.addma.2020.101645.

112. Bose S, Vahabzadeh S, Bandyopadhyay A. Bone tissue engineering using 3D printing. Mater Today. 2013;16:496-504 Available from: https://linkinghub.elsevier.com/retrieve/pii/ S136970211300401X.

113. Visser J, Peters B, Burger TJ, Boomstra J, Dhert WJA, Melchels FPW, et al. Biofabrication of multi-material anatomically shaped tissue constructs. Biofabrication. 2013;5:035007 Available from: https://iopscience.iop.org/article/10.1088/1758-5082/5/3/ 03500764.

114. Möller T, Amoroso M, Hägg D, Brantsing C, Rotter N, Apelgren $\mathrm{P}$, et al. In vivo chondrogenesis in 3D bioprinted human cell-laden hydrogel constructs. Plast Reconstr Surg - Glob Open. 2017;5: e1227 Available from: http://journals.lww.com/01720096$201702000-0001363$.

115. Zhang W, Lian Q, Li D, Wang K, Hao D, Bian W, et al. Cartilage repair and subchondral bone migration using $3 \mathrm{D}$ printing osteochondral composites: a one-year-period study in rabbit trochlea. Biomed Res Int. 2014;2014:1-16 Available from: http:/ www.hindawi.com/journals/bmri/2014/746138/48.

116. Kang H-W, Lee SJ, Ko IK, Kengla C, Yoo JJ, Atala A. A 3D bioprinting system to produce human-scale tissue constructs with structural integrity. Nat Biotechnol. 2016;34:312-9 Available from: http://www.nature.com/articles/nbt.341350.

117. Nyberg EL, Farris AL, Hung BP, Dias M, Garcia JR, Dorafshar $\mathrm{AH}$, et al. 3D-printing technologies for craniofacial rehabilitation, reconstruction, and regeneration. Ann Biomed Eng. 2017;45:4557 Available from: http://link.springer.com/10.1007/s10439-0161668-5.

118. Tao O, Kort-Mascort J, Lin Y, Pham HM, Charbonneau AM, ElKashty OA, et al. The applications of 3D printing for craniofacial tissue engineering. Micromachines. 2019;10:480 Available from: https://www.mdpi.com/2072-666X/10/7/480.

119. Ricci JL, Clark EA, Murriky A, Smay JE. Three-dimensional printing of bone repair and replacement materials. J Craniofac Surg. 2012;23:304-8 Available from: https://journals.lww.com/ 00001665-201201000-0007249.

120. Albrecht LD, Sawyer SW, Soman P. Developing 3D scaffolds in the field of tissue engineering to treat complex bone defects. 3D Print Addit Manuf. 2016;3:106-12 Available from: http://www. liebertpub.com/doi/10.1089/3dp.2016.000647.

121. Fedorovich NE, Wijnberg HM, Dhert WJA, Alblas J. Distinct tissue formation by heterogeneous printing of osteo- and endothelial progenitor cells. Tissue Eng Part A. 2011;17:2113-21 Available from: https://www.liebertpub.com/doi/10.1089/ten.tea. 2011.001946.

122. King SM, Gorgen V, Presnell SC, Nguyen DG, Shepherd BR. Development of 3D bioprinted human breast cancer for in vitro screening of therapeutics targeted against cancer progression. In Molecular Biology of the Cell. Bethesda: American Society Cell Biology; 2013.

123. Zhao Y, Yao R, Ouyang L, Ding H, Zhang T, Zhang K, et al. Three-dimensional printing of Hela cells for cervical tumor model in vitro. Biofabrication. 2014 Sep;6(3):035001. https://doi.org/10. 1088/1758-5082/6/3/035001.

124. Zuo KJ, Medina A, Tredget EE. Important developments in burn care. Plast Reconstr Surg. 2017;139:120e-38e Available from: http://www.ncbi.nlm.nih.gov/pubmed/2802725082. 
125. Snell JA, Loh N-HW, Mahambrey T, Shokrollahi K. Clinical review: the critical care management of the burn patient. Crit Care. 2013;17:241 Available from: http://ccforum.biomedcentral.com/ articles/10.1186/cc1270681.

126. Wang Y, Beekman J, Hew J, Jackson S, Issler-Fisher AC, Parungao R, et al. Burn injury: Challenges and advances in burn wound healing, infection, pain and scarring. Adv Drug Deliv Rev. 2018;123:3-17 Available from: https://linkinghub.elsevier.com/ retrieve/pii/S0169409X1730199080.

127. Halim A, Khoo T, Shah JY. Biologic and synthetic skin substitutes: an overview. Indian J Plast Surg. 2010;43:23 Available from: http://www.ijps.org/text.asp?2010/43/3/23/7071279.

128. Jakab K, Norotte C, Marga F, Murphy K, Vunjak-Novakovic G, Forgacs G. Tissue engineering by self-assembly and bio-printing of living cells. Biofabrication. 2010;2:022001 Available from: https://iopscience.iop.org/article/10.1088/1758-5082/2/2/ 02200177.

129. Chang R, Emami K, Wu H, Sun W. Biofabrication of a threedimensional liver micro-organ as an in vitro drug metabolism model. Biofabrication. 2010;2:045004 Available from: https:// iopscience.iop.org/article/10.1088/1758-5082/2/4/04500470.

130. Hong N, Yang G-H, Lee J, Kim G. 3D bioprinting and its in vivo applications. J Biomed Mater Res Part B Appl Biomater. 2018;106:444-59 Available from: http://doi.wiley.com/10.1002/ jbm.b.3382667.

131. Apelgren P, Amoroso M, Lindahl A, Brantsing C, Rotter N, Gatenholm P, et al. Chondrocytes and stem cells in 3Dbioprinted structures create human cartilage in vivo. Doh J, editor. PLoS One. 2017;12:e0189428. Available from: https://dx.plos. org/10.1371/journal.pone.018942866.

132. Nguyen D, Hägg DA, Forsman A, Ekholm J, Nimkingratana P, Brantsing C, et al. Cartilage tissue engineering by the 3D bioprinting of iPS cells in a nanocellulose/alginate bioink. Sci Rep. 2017;7:658 Available from: http://www.nature.com/ articles/s41598-017-00690-y65.

133. Murphy SV, Atala A. 3D bioprinting of tissues and organs. Nat Biotechnol. 2014;32:773-85 Available from: http://www.nature. com/articles/nbt.295862. Accessed 24/09/2020.

134. Steve Volk(editor). Engineering new organs using our own living cells. 2015. Available from: https://www.discovermagazine.com/ the-sciences/engineering-new-organs-using-our-own-livingcells61

135. Rushabh Haria. Kidney transplant using 3D printing marks a medical first in Belfast. 2018. Available from: https:// 3 dprintingindustry.com/news/kidney-transplant-using-3Dprinting-marks-medical-first-belfast-127743/60.

136. Wang Z, Lee SJ, Cheng H-J, Yoo JJ, Atala A. 3D bioprinted functional and contractile cardiac tissue constructs. Acta Biomater. 2018;70:48-56 Available from: https://linkinghub. elsevier.com/retrieve/pii/S174270611830077159.

137. Zhang YS, Arneri A, Bersini S, Shin S-R, Zhu K, GoliMalekabadi Z, et al. Bioprinting 3D microfibrous scaffolds for engineering endothelialized myocardium and heart-on-a-chip. Biomaterials. 2016;110:45-59 Available from: https:// linkinghub.elsevier.com/retrieve/pii/S014296121630477X58.

138. Coxworth B. Fully-formed, tiny heart is $3 \mathrm{D}$ bioprinted from human donor's cells. 2019; Available from: https://newatlas.com/ medical/bioprinted-human-heart57.

139. Nicholls M. Three-dimensional imaging and printing in cardiology. Eur Heart J. 2017;38:230-1 Available from: https://academic. oup.com/eurheartj/article/38/4/230/298103656.

140. Lee A, Hudson AR, Shiwarski DJ, Tashman JW, Hinton TJ, Yerneni S, et al. 3D bioprinting of collagen to rebuild components of the human heart. Science (80-). 2019;365:482-7 Available from: https://www.sciencemag.org/lookup/doi/10.1126/science. aav 905155 .
141. Noor N, Shapira A, Edri R, Gal I, Wertheim L, Dvir T. 3D printing of personalized thick and perfusable cardiac patches and hearts. Adv Sci. 2019;6:1900344 Available from: https://onlinelibrary. wiley.com/doi/10.1002/advs.20190034453.

142. Choi Y-J, Yi H-G, Kim S-W, Cho D-W. 3D Cell Printed Tissue analogues: a new platform for theranostics. Theranostics. 2017;7: 3118-37 Available from: http://www.ncbi.nlm.nih.gov/pubmed/ 2883946845

143. Norman J, Madurawe RD, Moore CMV, Khan MA, Khairuzzaman A. A new chapter in pharmaceutical manufacturing: 3D-printed drug products. Adv Drug Deliv Rev. 2017;108: 39-50 Available from: https://linkinghub.elsevier.com/retrieve/ pii/S0169409X1630077144.

144. Trenfield SJ, Awad A, Goyanes A, Gaisford S, Basit AW. 3D printing pharmaceuticals: drug development to frontline care. Trends Pharmacol Sci. 2018;39:440-51 Available from: https:// linkinghub.elsevier.com/retrieve/pii/S016561471830044043. Accessed 19/08/2020.

145. Liaw C-Y, Guvendiren M. Current and emerging applications of 3D printing in medicine. Biofabrication. 2017;9:024102 Available from: https://iopscience.iop.org/article/10.1088/1758-5090/ aa727942.

146. Chen G, Xu Y, Chi Lip Kwok P, Kang L. Pharmaceutical applications of 3D printing. Addit Manuf. 2020;34:101209 Available from: https://linkinghub.elsevier.com/retrieve/pii/ S221486042030581941.

147. Huang Y, Zhang X-F, Gao G, Yonezawa T, Cui X. 3D bioprinting and the current applications in tissue engineering. Biotechnol J. 2017;12:1600734 Available from: http://doi.wiley.com/10.1002/ biot. 20160073440 .

148. Nie J, Gao Q, Fu J, He Y. Grafting of 3D Bioprinting to in vitro drug screening: a review. Adv Healthc Mater. 2020;9:1901773 Available from: https://onlinelibrary.wiley.com/doi/abs/10.1002/ adhm.20190177339. Accessed 19/08/2020.

149. Satpathy A, Datta P, Wu Y, Ayan B, Bayram E, Ozbolat IT. Developments with 3D bioprinting for novel drug discovery. Expert Opin Drug Discovery. 2018;13:1115-29 Available from: https://www.tandfonline.com/doi/full/10.1080/17460441.2018. 154242738 .

150. Datta P, Ayan B, Ozbolat IT. Bioprinting for vascular and vascularized tissue biofabrication. Acta Biomater. 2017;51:1-20 Available from: https://linkinghub.elsevier.com/retrieve/pii/ S174270611730035137.

151. Harrison RG. The outgrowth of the nerve fiber as a mode of protoplasmic movement. J Exp Zool. 1959;142:5-73 Available from: http://doi.wiley.com/10.1002/jez.140142010336.

152. Kijanska M, Kelm J. In vitro 3D spheroids and microtissues: ATPbased cell viability and toxicity assays. Assay Guid Man. 2004. Available from: http://www.ncbi.nlm.nih.gov/pubmed/ 2684433235

153. Amann A, Zwierzina M, Gamerith G, Bitsche M, Huber JM, Vogel GF, et al. Development of an innovative 3D cell culture system to study tumour - stroma interactions in non-small cell lung cancer cells. Gullberg D, editor. PLoS One . 2014;9:e92511. Available from: https://dx.plos.org/10.1371/journal.pone. 009251134

154. Yu S, Joshi P, Park YJ, Yu K-N, Lee M-Y. Deconvolution of images from 3D printed cells in layers on a chip. Biotechnol Prog. 2018;34:445-54 Available from: http://doi.wiley.com/10. 1002/btpr.259133.

155. Devarasetty M, Mazzocchi AR, Skardal A. Applications of bioengineered 3D tissue and tumor organoids in drug development and precision medicine: current and future. BioDrugs. 2018;32:53-68 Available from: http://link.springer.com/10. 1007/s40259-017-0258-x32. 
156. Jalili-Firoozinezhad S, Prantil-Baun R, Jiang A, Potla R, Mammoto $\mathrm{T}$, Weaver $\mathrm{JC}$, et al. Modeling radiation injuryinduced cell death and countermeasure drug responses in a human Gut-on-a-Chip. Cell Death Dis. 2018;9:223. Available from: $\mathrm{http} / / / w w w . n a t u r e . c o m / a r t i c l e s / s 41419-018-0304-831$.

157. Huang J, Ren Y, Wu X, Li Z, Ren J. Gut bioengineering promotes gut repair and pharmaceutical research: a review. J Tissue Eng. 2019;10:204173141983984 Available from: http://journals. sagepub.com/doi/10.1177/204173141983984627.

158. Han S, Kim S, Chen Z, Shin HK, Lee S-Y, Moon HE, et al. 3D Bioprinted vascularized tumour for drug testing. Int J Mol Sci. 2020;21:2993 Available from: https://www.mdpi.com/14220067/21/8/299326. Accessed 20/08/2020.

159. Zhao Y, Yao R, Ouyang L, Ding H, Zhang T, Zhang K, et al. Three-dimensional printing of Hela cells for cervical tumor model in vitro. Biofabrication. 2014;6:035001 Available from: https:// iopscience.iop.org/article/10.1088/1758-5082/6/3/03500124.

160. Langer EM, Allen-Petersen BL, King SM, Kendsersky ND, Turnidge MA, Kuziel GM, et al. Modeling tumor phenotypes in vitro with three-dimensional bioprinting. Cell Rep. 2019;26: 608-623.e6 Available from: https://linkinghub.elsevier.com/ retrieve/pii/S221112471832050323.

161. Ishack S, Lipner SR. Applications of 3D printing technology to address COVID-19-related supply shortages. Am J Med. 2020;133:771-3 Available from: https://linkinghub.elsevier.com/ retrieve/pii/S000293432030332622. Accessed 21/08/2020.

162. Armijo PR, Markin NW, Nguyen S, Ho DH, Horseman TS, Lisco $\mathrm{SJ}$, et al. 3D printing of face shields to meet the immediate need for PPE in an anesthesiology department during the COVID-19 pandemic. Am J Infect Control. 2021;49:302-8 Available from: https://1inkinghub.elsevier.com/retrieve/pii/ S019665532030762821. Accessed 20/08/2020.

163. Tino R, Moore R, Antoline S, Ravi P, Wake N, Ionita CN, et al. COVID-19 and the role of 3D printing in medicine. 3D Print Med. 2020;6:11 Available from: https://threedmedprint.biomedcentral. com/articles/10.1186/s41205-020-00064-720. Accessed 21/08/ 2020

164. Hsiao W-K, Lorber B, Paudel A. Can 3D printing of oral drugs help fight the current COVID-19 pandemic (and similar crisis in the future)? Expert Opin Drug Deliv [ spacebar]. 2020;17:899902 Available from: https://www.tandfonline.com/doi/full/10. 1080/17425247.2020.177222919. Accessed 20/08/2020.

165. Cox JL, Koepsell SA. 3D-printing to address COVID-19 testing supply shortages. Lab Med. 2020;51(4):e45-6. https://doi.org/10. 1093/labmed/lmaa031. Accessed 20/08/2020.

166. Thakkar R, Pillai AR, Zhang J, Zhang Y, Kulkarni V, Maniruzzaman M. Novel on-demand 3-dimensional (3-D) printed tablets using fill density as an effective releasecontrolling tool. Polymers (Basel). 2020;12(9):1872. https://doi. org/10.3390/polym12091872.

167. Nacharaju D, Menzel W, Fontaine E, Child D, El Haddi SJ, Nonas $\mathrm{S}$, et al. Three-dimensional printed ventilators: a rapid solution to coronavirus disease 2019-induced supply-chain shortages. Crit Care Explor. 2020;2(10):e0226. https://doi.org/10.1097/CCE. 0000000000000226.

168. Wan Z, Zhang P, Liu Y, Lv L, Zhou Y. Four-dimensional bioprinting: current developments and applications in bone tissue engineering. Acta Biomater. 2020;101:26-42 Available from: https://linkinghub.elsevier.com/retrieve/pii/ S174270611930717218.

169. Tibbits S. 4D printing: multi-material shape change. Archit Des. 2014;84:116-21 Available from: http://doi.wiley.com/10.1002/ ad.171017. Accessed 19/12/2020.
170. Gao B, Yang Q, Zhao X, Jin G, Ma Y, Xu F. 4D bioprinting for biomedical applications. Trends Biotechnol. 2016;34:746-56 Available from: https://linkinghub.elsevier.com/retrieve/pii/ S016777991600066416.

171. Ionov L. 4D biofabrication: materials, methods, and applications. Adv Healthc Mater. 2018;7:1800412. Available from: http://doi. wiley.com/10.1002/adhm.20180041215.

172. Ashammakhi N, Ahadian S, Zengiie F, Suthiwanich K, Lorestani $\mathrm{F}$, Orive $\mathrm{G}$, et al. Advances and future perspectives in $4 \mathrm{D}$ bioprinting. Biotechnol. 2018;13:1800148 Available from: https://onlinelibrary.wiley.com/doi/abs/10.1002/biot. 20180014814.

173. Wei M, Gao Y, Li X, Serpe MJ. Stimuli-responsive polymers and their applications. Polym Chem. 2017;8:127-43 13.

174. Ashammakhi N, Kaarela O. Stimuli-responsive biomaterials: next wave. J Craniofac Surg. 2017;28:1647-8 Available from: https:// journals.lww.com/00001665-201710000-0000312.

175. Yang Q, Gao B, Xu F. Recent advances in 4D bioprinting. Biotechnol J. 2020;15:1900086 Available from: https:// onlinelibrary.wiley.com/doi/abs/10.1002/biot.20190008611.

176. Gao B, Yang Q, Zhao X, Jin G, Ma Y, Xu F. 4D bioprinting for biomedical applications. Trends Biotechnol. 2016;34:746-56 Available from: https://linkinghub.elsevier.com/retrieve/pii/ S016777991600066410.

177. Khoo ZX, Teoh JEM, Liu Y, Chua CK, Yang S, An J, et al. 3D printing of smart materials: a review on recent progresses in 4D printing. Virtual Phys Prototyp. 2015;10:103-22 9.

178. Villar G, Heron AJ, Bayley H. Formation of droplet networks that function in aqueous environments. Nat Nanotechnol. 2011;6:8038 Available from: http://www.nature.com/articles/nnano.2011. 1838.

179. Tseng L-F, Wang J, Baker RM, Wang G, Mather PT. Henderson $\mathrm{JH}$ Osteogenic capacity of human adipose-derived stem cells is preserved following triggering of shape memory scaffolds. Tissue Eng Part A. 2016;22:1026-35 Available from: https://www. liebertpub.com/doi/10.1089/ten.tea.2016.00957.

180. Li P, Zhang W, Smith LJ, Ayares D, Cooper DKC, Ekser B. The potential role of 3D-bioprinting in xenotransplantation. Curr Opin Organ Transplant. 2019;24:547-54 Available from: http:// journals.lww.com/00075200-201910000-000086.

181. Sego TJ, Kasacheuski U, Hauersperger D, Tovar A, Moldovan NI. A heuristic computational model of basic cellular processes and oxygenation during spheroid-dependent biofabrication. Biofabrication. 2017;9(2):024104. https://doi.org/10.1088/17585090/aa6ed4.

182. Smood B, Hara H, Schoel LJ, Cooper DKC. Geneticallyengineered pigs as sources for clinical red blood cell transfusion: what pathobiological barriers need to be overcome? Blood Rev. 2019;35:7-17 Available from: https://linkinghub.elsevier.com/ retrieve/pii/S0268960X1830095X4.

183. Shah JA, Lanaspa MA, Tanabe T, Watanabe H, Johnson RJ, Yamada K. Remaining physiological barriers in porcine kidney xenotransplantation: potential pathways behind proteinuria as well as factors related to growth discrepancies following pig-to-kidney xenotransplantation. J Immunol Res. 2018;2018:1-6 Available from: https://www.hindawi.com/journals/jir/2018/6413012/3.

184. Hozain AE, O'Neill JD, Pinezich MR, Tipograf Y, Donocoff R, Cunningham KM, et al. Xenogeneic cross-circulation for extracorporeal recovery of injured human lungs. Nat Med. 2020;26(7): 1102-13. https://doi.org/10.1038/s41591-020-0971-8.

Publisher's Note Springer Nature remains neutral with regard to jurisdictional claims in published maps and institutional affiliations. 